\title{
The impact of business regulatory reforms on economic growth
}

\author{
Jamal Ibrahim Haidar* \\ The World Bank, Washington, DC, United States \\ Paris School of Economics, Paris, France \\ University of Paris 1 Pantheon-Sorbonne, Paris, France
}

\section{A R T I C L E I N F O}

\section{Article history:}

Received 24 June 2011

Revised 12 May 2012

Available online 25 May 2012

\section{JEL classification:}

012

017

050

P48

Keywords:

Growth

Reform

Development

Regulations

Doing Business

Institutions

\section{A B S T R A C T}

Haidar, Jamal Ibrahim-The impact of business regulatory reforms on economic growth

I investigate the link between business regulatory reforms and economic growth in 172 countries. I create a 5 year dataset on business regulatory reforms from the World Bank's Doing Business reports. Then, I test the hypothesis that business regulatory reforms increase economic growth, using data on micro-economic reforms. These data do not suffer the endogeneity issues associated with other datasets on changes in economic institutions. The results provide a robust support for the claim that business regulatory reforms are good for economic growth. The paper establishes that, on average, each business regulatory reform is associated with a $0.15 \%$ increase in growth rate of GDP. J. Japanese Int. Economies 26 (3) (2012) 285-307. The World Bank, Washington, DC, United States; Paris School of Economics, Paris, France; University of Paris 1 Pantheon-Sorbonne, Paris, France.

(c) 2012 Elsevier Inc. All rights reserved.

\section{Introduction}

The World Bank has been publishing the annual Doing Business reports since 2004 to investigate the scope and manner of regulations that enhance business activity and those that constrain it. These reports compare countries ${ }^{1}$ on the basis of quantitative indicators of business regulations. A fundamental premise of business regulations is that economic activity requires good rules - rules that establish and

\footnotetext{
* Address: Paris School of Economics, Paris, France.

E-mail addresses: JHaidar@worldbank.org, Jamal.Haidar@ParisSchoolofEconomics.Eu, Jamal.Haidar@malix.univ-paris1.fr

1 The Doing Business 2011 dataset covers 183 countries.
} 
clarify property rights and reduce the cost of resolving disputes; rules that increase the predictability of economic interactions and provide contractual partners with certainty and protection against abuse (Acemoglu et al., 2001; Djankov et al., 2002). The objective is regulations designed to be efficient, accessible to all and simple in their implementation. Djankov et al. (2006) and Haidar (2009) show in cross country regressions that burdensome business regulatory procedures are negatively correlated with GDP growth. This paper is different in two different ways. First, while Djankov et al. (2006) and Haidar (2009) focus on 1 year, much less countries, a lower number of indicators, and a narrower geographic scope, this paper looks at a 5-year period, a larger regulatory scope, and a broader set of countries. Second, the main independent variable in Djankov et al. (2006) and Haidar (2009) is different. The authors look at the regulatory status at 1 year but this paper considers a more interesting and important variable, regulatory reform (not status) at a given year and over time. They consider that growth is a function of the existing regulatory framework. I argue that the level of income can be a function of existing regulatory framework but a change in income level is more of a function of how regulatory framework changes and improves.

This paper uses the World Bank Doing Business indicators as proxies of business regulations, identifies business regulatory reforms by Doing Business reforms, and goes further towards answering the question about whether regulatory reforms enhance economic growth by studying a major determinant of economic growth: regulatory reforms governing business activity.

A vibrant private sector - with firms making investments, creating jobs, and improving productivity - promotes growth and expands opportunities for poor people (OECD and World Bank, 2006). To strengthen private sector, governments around the world have implemented wide-ranging reforms, including macro-stabilization programs, price liberalization, privatization, and trade-barrier reductions. In many countries, however, entrepreneurial activity remains limited, poverty stays high, and growth is not significantly far from stagnant. And other countries have spurned orthodox macro reforms and done well.

Although macro policies are unquestionably important, there is a growing consensus that the quality of business regulation and the institutions that enforce it are a major determinant of prosperity. Hong Kong (China)'s economic success, Botswana's stellar growth performance, and Hungary's smooth transition experience have all been stimulated by a good business regulatory environment. ${ }^{2}$ However, little research has measured specific aspects of business regulation and analyzed their impact on economic outcomes such as growth, productivity, investment, informality, corruption, unemployment, and poverty. The lack of systematic knowledge prevents policymakers from assessing how good legal and regulatory systems are and determining what to reform.

The World Bank Doing Business regulatory indicators have four key goals. First, they aim to motivate reforms through country benchmarking. Second, they try to inform the design of reforms by highlighting specifically what needs to be changed. Third, the dataset enriches international initiatives on development effectiveness. Fourth, the dataset tries to inform theory by producing new indicators that quantify various aspects of regulation, facilitating tests of existing theories, and contributing to the empirical foundation for new theoretical work on the relation between regulation and development.

Governments around the world reported 1140 business regulatory reforms over the 5 years up to $2010 .^{3}$ Against the backdrop of the global financial and economic crisis, policy makers around the world continue to reform business regulations at the level of the firm, in some areas at an even faster pace than before. Most reforms were nested in broader programs of investment climate reform aimed at enhancing economic competitiveness, as in Colombia, Kenya, and Liberia. In structuring their reform programs for the business environment, governments use multiple data sources and indicators. And, reformers respond to many stakeholders and interest groups, all of whom bring important issues and concerns to the debate. World Bank Group dialogue with governments on the investment climate is designed to encourage critical use of the data, sharpen judgment, avoid a narrow focus on improving rankings, and encourage broad-based reforms that enhance the investment climate. These continued efforts

\footnotetext{
2 See the World Bank Doing Business (2004) report for details.

${ }^{3}$ We deduce these reforms from the annual Doing Business reports. The paper looks at these five specific years for (i) data consistency and (ii) higher country coverage.
} 
prompt questions: What is the impact of business regulatory reforms on economic growth? This paper aims to present new findings toward answering this question.

The paper proceeds as follows. Section 2 reviews literature. Section 3 describes data. Section 4 presents main empirical results. Section 5 provides robustness checks, and Section 6 concludes.

\section{Literature review}

Hall and Jones (1999), Acemoglu et al. (2001), Djankov et al. (2002, 2003, 2004, 2006), among others $^{4}$ show that institutions are a major determinant of wealth and long-term growth. Countries that had better political and economic institutions in the past are richer today. I add to the literature on institutions and growth by studying a new measure of institutional reforms. The analysis focuses on a particular type of institutional reforms: business regulations. I use a new country-level data set to establish the impact of business regulatory reforms on economic growth.

The relationship between regulations and business activity has been under investigation in many academic circles in many articles over the last two decades. Winston (1998) provides a literature review, finds that business regulations affect large and most concentrated industries and are sector-specific. However, much fewer studies look at the impact of business regulatory reforms on economic growth, partly due to lack of data availability. This study tries to fill a research gap by addressing business regulatory reforms impact on economic growth.

Various empirical studies look at business regulations trends across countries over the last decade. Djankov et al. (2002) presents new data on the regulation of entry of start-up firms in 85 countries. Countries with heavier regulation of entry have higher corruption and larger unofficial economies, but not better quality of public or private goods. Countries with more democratic and limited governments have lighter regulation of entry. Djankov et al. (2003) finds that formalism is systematically greater in civil than in common law countries, and is associated with higher expected duration of judicial proceedings, less consistency, less honesty, less fairness in judicial decisions, and more corruption. These results suggest that legal transplantation may have led to an inefficiently high level of procedural formalism, particularly in developing countries. Djankov et al. (2004) investigates the regulation of labor markets through employment, collective relations, and social security laws in 85 countries. They find that heavier regulation of labor is associated with lower labor force participation and higher unemployment, especially of the young.

On a related front, Conway et al. (2005) shows that within some countries product market policies have become more consistent across different regulatory provisions, although relatively restrictive countries still tend to have a more heterogeneous approach to competition. In general, domestic barriers to competition tend to be higher in countries that have higher barriers to foreign trade and investment, and high levels of state control and barriers to competition. Also, Djankov et al. (2010) established the impact of time delays on international trade. They estimated a difference gravity equation that controls for remoteness, and find that each additional day that a product is delayed prior to being shipped reduces trade by more than $1 \%$. The results that I establish in this paper (in the main regressions and in Appendix Table A8) are related to the latter paper. Appendix Table A8 shows that each positive reform in trading-across-borders regulations (i.e. time, costs, and procedures needed to export or import a cargo) is associated with a $0.88 \%$ increase in average economic growth rate. Thus, this paper also highlights the importance of reducing trade costs (as opposed to tariff barriers) to stimulate economic growth.

Starting early 2000s, articles focusing on the effect of regulations on economic fundamentals appeared. On the business entry regulations front, Desai et al. (2003) finds cross-country correlations between entry regulations and firm entry rates. They explore the impact of the institutional environment on the nature of entrepreneurial activity across Europe. Greater fairness and greater protection of property rights increase entry rates, reduce exit rates, and lower average firm size. Moreover, Klapper et al. (2004) uses a comprehensive database of firms in Western and Eastern Europe to study how the

\footnotetext{
${ }^{4}$ i.e. Amin and Haidar (2011), Haidar (2009), and Amin and Haidar (forthcoming). Haidar (2009) looks at how the state of investors protections affects income level and growth at one given year. However, this paper looks at how changes in investor protections, among nine other regulatory aspects, in a given country affect its income growth over time.
} 
business environment in a country drives the creation of new firms. They find entry regulations hamper entry, especially in industries that naturally should have high entry. Also, value-added per employee in naturally "high entry" industries grow more slowly in countries with onerous regulations on entry. And, Viviano (2008) exploits reforms to regional entry regulations in the Italian retail trade sector, finding that entry barriers have a negative impact on employment growth and on the efficiency of small firms.

On the labor regulations front, Scarpetta et al. (2002) use firm-level survey data from OECD countries to analyze firm entry and exit, finding that higher product market and labor regulations are negatively correlated with the entry of small and medium sized firms. In addition, Hasan et al. (2007) find that labor demand elasticities in Indian manufacturing industries are higher for Indian states with more flexible labor regulations. And, Besley and Burgess (2004) find that Indian states which imposed tighter labor regulations experienced reduced manufacturing output, employment, investment and productivity in formal sector manufacturing and increased output in informal manufacturing.

\section{Data description}

The sample consists of 172 countries for which information on the main variables is available. The time period covered by the study is 2006-2010. In the analysis, I utilize several sources of data including the World Bank's Doing Business annual reports, World Development Indicators, Polity IV, and Freedom House. Table 1 provides a definition of all variables and their sources. Table 2 provides summary statistics, and Table 3 provides correlations between the main variables.

\subsection{Dependent variable}

This study primarily focuses on one dependent variable: annual percentage growth rate of income per capita, available from the World Bank's World Development Indicators (WDI). I use the WDI because it covers a larger set of countries than the Penn World Tables used by Hall and Jones (1999). By way of context, 2006-2010 was a period of relatively mixed (strong and weak) economic performance across the world. For developed countries, 2006 marked recovery after the US slump of 2001-2005. Among developing countries, some experienced sharp downturns - notably Argentina and Zimbabwe - but most have enjoyed growth rates in excess of those of the 1980s and 1990s. GDP growth rates averaged 3.92, and this average growth rate ranged between $-6.3 \%$ (Zimbabwe) and $19.9 \%$ (Azerbaijan), as shown in Table 2.

\subsection{Explanatory variables}

I deduce the main independent variable from World Bank's Doing Business annual reports. As part of its annual exercise, Doing Business compiles 10 sets of indicators covering various aspects of the business climate including starting a business, paying taxes, obtaining licenses, getting credit, protecting investors, employing workers, international trade, property registration, closing a business and enforcement of private contracts. The annual Doing Business report includes information on important reforms on each of these indicators. I code this information as a dummy variable which equals 1 if a country implemented a positive reform during the year on a given indicator and 0 otherwise. A positive reform, as defined in Doing Business reports, is one that makes it faster, cheaper or administratively easier for local businesses to start and run operations; or a reform that defines and increases the protection of property rights. An example is reducing the number of days to get an industry license, eliminating the minimum capital requirement for start-ups, or increasing the legal rights of creditors and minority shareholders.

Using this dataset, I define the main independent variable, Reform, as the total number of reforms happening in a country during a certain period of time (i.e. 2006-2010 in Table 4 and 2006-2008 in Table 5). Each individual reform is coded as a dummy variable equal to 1 if a positive reform occurred in one or more of the 10 indicators in a given year and 0 otherwise. The mean value of the variable equals 6.51 and the standard deviation is 4.67 (Table 2). For example, between 2006 and 2010, 
Table 1

Description of variables.

\begin{tabular}{|c|c|}
\hline Variable & Description \\
\hline Economic growth & $\begin{array}{l}\text { Average GDP growth rates (PPP adjusted and at constant } 2005 \text { USD). We take the average value } \\
\text { of the variable over 2006-2010. Source: World Development Indicators, World Bank }\end{array}$ \\
\hline Regulatory reforms & $\begin{array}{l}\text { Total business regulatory reforms as measured by the Doing Business Indices. We use total } \\
\text { number of reforms over 2006-2010. A measure of the improvement of the quality of the } \\
\text { business climate as experienced by the firms. Doing Business compiles } 10 \text { sets of indicators } \\
\text { covering various aspects of the business climate including starting a business, paying taxes, } \\
\text { obtaining licenses, getting credit, protecting investors, employing workers, international trade, } \\
\text { property registration, closing a business and enforcement of private contracts. Information is } \\
\text { also available on an annual basis on important reforms on each of these indicators. This } \\
\text { information is coded as a dummy variable which equals } 1 \text { if a country implemented a positive } \\
\text { reform during the year on a given indicator and } 0 \text { otherwise. Source: Doing Business, World } \\
\text { Bank }\end{array}$ \\
\hline $\begin{array}{r}\text { Foreign direct } \\
\text { investment }\end{array}$ & $\begin{array}{l}\text { Net foreign direct investment as a percentage of GDP. Average values over } 2006-2010 \text { are used. } \\
\text { Source: World Development Indicators, World Bank }\end{array}$ \\
\hline $\begin{array}{l}\text { Fixed capital formation } \\
\text { growth }\end{array}$ & $\begin{array}{l}\text { Average annual growth of gross fixed capital formation based on constant local currency. } \\
\text { Aggregates are based on constant } 2005 \text { US dollars. Gross fixed capital formation (formerly gross } \\
\text { domestic fixed investment) includes land improvements (fences, ditches, drains, and so on); } \\
\text { plant, machinery, and equipment purchases; and the construction of roads, railways, and the } \\
\text { like, including schools, offices, hospitals, private residential dwellings, and commercial and } \\
\text { industrial buildings. Average values over 2006-2010 are used. Source: World Development } \\
\text { Indicators, World Bank }\end{array}$ \\
\hline Population & $\begin{array}{l}\text { Log of average population of the country. Average values over 2006-2010 are used. Source: } \\
\text { World Development Indicators, World Bank }\end{array}$ \\
\hline Trade & $\begin{array}{l}\text { The sum of exports and imports as a as a percentage of GDP. Average values over 2006-2010 } \\
\text { are used. Source: World Development Indicators, World Bank }\end{array}$ \\
\hline Government spending & $\begin{array}{l}\text { The level of government expenditures as a percentage of GDP. Average values over 2006-2010 } \\
\text { are used. Government expenditures, including consumption and transfers, account for the } \\
\text { entire score. Source: Heritage Foundation }\end{array}$ \\
\hline Financial freedom & $\begin{array}{l}\text { Financial freedom is a measure of banking efficiency as well as a measure of independence from } \\
\text { government control and interference in the financial sector. Average values over 2006-2010 are } \\
\text { used. Source: Heritage Foundation }\end{array}$ \\
\hline Political stability & $\begin{array}{l}\text { The political stability and absence of violence indicator measures the perceptions of the } \\
\text { likelihood that the government will be destabilized or overthrown by unconstitutional or } \\
\text { violent means, including domestic violence and terrorism. Values are indexed to have a mean of } \\
\text { zero and a standard deviation of one index unit. Positive scores indicate better governance and } \\
99 \% \text { of the values fall between } 2.5 \text { and -2.5. Average values over 1996-2009 are used. Source: } \\
\text { Kaufmann et al. (2009) }\end{array}$ \\
\hline Rule of law & $\begin{array}{l}\text { The Rule of Law Index is a measure of "the extent to which agents have confidence in and abide } \\
\text { by the rules of society." The degree to which a society's atmosphere is conducive to regular, } \\
\text { orderly social and economic activity and the protection of private property is an important } \\
\text { measure of government effectiveness. Values are indexed to have a mean of zero and a standard } \\
\text { deviation of one index unit. Positive scores indicate better governance and } 99 \% \text { of the values fall } \\
\text { between } 2.5 \text { and - } 2.5 \text {. Average values over } 1996-2009 \text { are used. Source: Kaufmann et al. (2009) }\end{array}$ \\
\hline Control of corruption & $\begin{array}{l}\text { The average level of the "freedom from corruption" score as measured by the Heritage } \\
\text { Foundation's Index of Economic Freedom, where the average is taken over 1996-2009 values. } \\
\text { Source: Heritage Foundation }\end{array}$ \\
\hline
\end{tabular}

Trinidad and Tobago implemented reforms in paying taxes and access to credit implying a score of 2 for the independent variable.

In addition to the main independent variable, Reform, I ran 10 separate regressions using the main independent variable as the total number of reforms in each category of regulatory reforms. The results hold. I show the 10 separate regressions in the Appendix (Tables A1-A10).

Information on changes in the quality of the business environment is also available from alternative sources such as Heritage Foundation's Freedom of the World Index or Fraser Institute's Economic Freedom of the World. One could use annual changes in these data to construct a measure of reform similar to the ones described above. However, I use the Doing Business data as I consider that it offers 
Table 2

Summary statistics.

\begin{tabular}{|c|c|c|c|c|c|}
\hline Variable & Mean & Std. deviation & Minimum & Maximum & $\begin{array}{l}\text { Observations } \\
\text { (countries) }\end{array}$ \\
\hline Economic growth & 3.93 & 3.12 & -6.3 & 19.91 & 172 \\
\hline Regulatory reforms & 6.51 & 4.67 & 0 & 23 & 175 \\
\hline Foreign direct investment & 6.05 & 6.22 & -8.51 & 27.80 & 166 \\
\hline Fixed capital formation growth & 6.67 & 9.058 & -18.99 & 63.12 & 117 \\
\hline Population & 15.71 & 2.015 & 9.91 & 21.01 & 174 \\
\hline Trade & 93.50 & 52.12 & 25.26 & 422.02 & 161 \\
\hline Government spending & 65.13 & 22.55 & 0 & 94.73 & 164 \\
\hline Financial freedom & 49.62 & 18.01 & 10 & 90 & 164 \\
\hline Political stability & -0.09 & 0.97 & -2.88 & 1.21 & 160 \\
\hline Rule of law & -0.09 & 0.94 & -1.89 & 1.89 & 171 \\
\hline Control of corruption & -0.06 & 0.95 & -1.627 & 2.33 & 173 \\
\hline
\end{tabular}

Table 3

Correlation between main variables.

\begin{tabular}{|c|c|c|c|c|c|c|c|c|c|c|c|}
\hline & $(1)$ & $(2)$ & (3) & (4) & $(5)$ & (6) & (7) & (8) & (9) & $(10)$ & (11) \\
\hline $\begin{array}{l}\text { Dependent variable: Economic } \\
\text { growth }\end{array}$ & 1 & & & & & & & & & & \\
\hline Regulatory reforms & 0.27 & 1 & & & & & & & & & \\
\hline Foreign direct investment & -0.05 & 0.05 & 1 & & & & & & & & \\
\hline Fixed capital formation growth & 0.45 & 0.10 & 0.16 & 1 & & & & & & & \\
\hline Population & 0.24 & 0.12 & -0.14 & 0.05 & 1 & & & & & & \\
\hline Trade & -0.05 & 0.05 & 0.59 & -0.05 & -0.19 & 1 & & & & & \\
\hline Government spending & 0.47 & 0.04 & -0.18 & 0.23 & 0.13 & -0.14 & 1 & & & & \\
\hline Financial freedom & -0.40 & -0.05 & 0.26 & -0.30 & -0.18 & 0.29 & -0.32 & 1 & & & \\
\hline Political stability & -0.37 & -0.18 & 0.14 & -0.22 & -0.16 & 0.26 & -0.57 & 0.42 & 1 & & \\
\hline Rule of law & -0.45 & -0.13 & 0.13 & -0.41 & -0.04 & 0.23 & -0.61 & 0.66 & 0.75 & 1 & \\
\hline Control of corruption & -0.48 & -0.20 & 0.12 & -0.38 & -0.08 & 0.20 & -0.63 & 0.63 & 0.72 & 0.97 & 1 \\
\hline
\end{tabular}

two advantages. First, unlike other data sources that are based in part on experts' perceptions, the Doing Business data are based on actual reforms. Second, and more important, since the Doing Business data cover a specific set of policy reforms, reverse causality from the dependent variable to reform is unlikely. It is difficult, for example, to imagine that the enactment of higher growth rates leads to more efficient bankruptcy law and, hence, would influence the societal bend towards reform. In contrast, other available indicators of the business environment are aggregate or macro level measures. Glaeser et al. (2006), among others, highlight a plausible feedback from macro level changes in the business environment to growth rates.

The main empirical specifications below are relatively sparse, given the use of within-country variation, the limited quantity of data, and the desire to maximize the number of usable observations. Because the main threat to econometric identification comes from unobserved economy - boosting public sector actions taken with similar timing to the observed regulatory reforms - the other control variables are chosen to capture these factors.

First, I include yearly averages of two measures of the quality of government policies and institutions from the World Governance Indicators (WGI). I aggregate the WGl's indices of rule of law, political stability, and control of corruption into average indices. These three indicators contain aggregate indicators of two dimensions of governance. The indicators are constructed using an unobserved components methodology. The three governance indicators are measured in units ranging from about -2.5 to 2.5, with higher values corresponding to better governance outcomes. Significant changes in the attitudes or policies of governments towards the private sector and changes in the risk environment facing investors should be picked up in these indices, helping to address potential biases associated with correlation between such changes and the observed regulatory reforms. 
Table 4

Regression results.

\begin{tabular}{|c|c|c|c|c|c|c|c|c|c|c|}
\hline & (1) & (2) & (3) & (4) & (5) & (6) & (7) & $(8)$ & (9) & (10) \\
\hline \multicolumn{11}{|l|}{$\begin{array}{l}\text { Dependent variable: } \\
\text { Economic growth }\end{array}$} \\
\hline Regulatory reforms & $\begin{array}{l}0.150^{n+*} \\
{[0.003]}\end{array}$ & $\begin{array}{l}0.129^{* * *} \\
{[0.009]}\end{array}$ & $\begin{array}{l}0.145^{* * *} \\
{[0.008]}\end{array}$ & $\begin{array}{l}0.130^{* *} \\
{[0.015]}\end{array}$ & $\begin{array}{l}0.128^{* *} \\
{[0.017]}\end{array}$ & $\begin{array}{l}0.131^{n+*} \\
{[0.007]}\end{array}$ & $\begin{array}{l}0.132^{* * *} \\
{[0.006]}\end{array}$ & $\begin{array}{l}0.133^{* * *} \\
{[0.008]}\end{array}$ & $\begin{array}{l}0.134^{* * *} \\
{[0.008]}\end{array}$ & $\begin{array}{l}0.114 \\
{[0.036]}\end{array}$ \\
\hline Foreign direct investment & & $\begin{array}{l}-0.033 \\
{[0.381]}\end{array}$ & $\begin{array}{l}-0.067 \\
{[0.164]}\end{array}$ & $\begin{array}{l}-0.051 \\
{[0.286]}\end{array}$ & $\begin{array}{l}-0.074 \\
{[0.214]}\end{array}$ & $\begin{array}{l}-0.036 \\
{[0.510]}\end{array}$ & $\begin{array}{l}-0.018 \\
{[0.735]}\end{array}$ & $\begin{array}{l}-0.021 \\
{[0.712]}\end{array}$ & $\begin{array}{l}-0.019 \\
{[0.738]}\end{array}$ & $\begin{array}{l}-0.018 \\
{[0.726]}\end{array}$ \\
\hline $\begin{array}{l}\text { Fixed capital formation } \\
\text { growth }\end{array}$ & & & $\begin{array}{l}0.151^{* * *} \\
{[0.000]}\end{array}$ & $\begin{array}{l}0.147^{* * *} \\
{[0.000]}\end{array}$ & $\begin{array}{l}0.150^{*+3} \\
{[0.000]}\end{array}$ & $\begin{array}{l}0.121^{\ldots+*} \\
{[0.000]}\end{array}$ & $\begin{array}{l}0.103^{* * *} \\
{[0.000]}\end{array}$ & $\begin{array}{l}0.102^{* * *} \\
{[0.000]}\end{array}$ & $\begin{array}{l}0.106^{* * *} \\
{[0.000]}\end{array}$ & $\begin{array}{l}0.110^{*} \\
{[0.000]}\end{array}$ \\
\hline Population & & & & $\begin{array}{l}0.000^{*} \\
{[0.027]}\end{array}$ & $\begin{array}{l}0.000 \\
{[0.023]}\end{array}$ & $\begin{array}{l}0.000^{*} \\
{[0.034]}\end{array}$ & $\begin{array}{l}0.000^{*} \\
{[0.058]}\end{array}$ & $\begin{array}{l}0.000^{*} \\
{[0.063]}\end{array}$ & $\begin{array}{l}0.000^{\circ} \\
{[0.097]}\end{array}$ & $\begin{array}{l}0.000 \\
{[0.164]}\end{array}$ \\
\hline Trade & & & & & $\begin{array}{l}0.004 \\
{[0.512]}\end{array}$ & $\begin{array}{l}0.005 \\
{[0.384]}\end{array}$ & $\begin{array}{l}0.006 \\
{[0.251]}\end{array}$ & $\begin{array}{l}0.006 \\
{[0.299]}\end{array}$ & $\begin{array}{l}0.006 \\
{[0.307]}\end{array}$ & $\begin{array}{l}0.006 \\
{[0.317]}\end{array}$ \\
\hline Government spending & & & & & & $\begin{array}{l}0.049^{1+*} \\
{[0.000]}\end{array}$ & $\begin{array}{l}0.043^{*+4} \\
{[0.000]}\end{array}$ & $\begin{array}{l}0.043^{* *+*} \\
{[0.001]}\end{array}$ & $\begin{array}{l}0.045^{+* *} \\
{[0.001]}\end{array}$ & $\begin{array}{l}0.046^{*} \\
{[0.002]}\end{array}$ \\
\hline Financial freedom & & & & & & & $\begin{array}{l}-0.034^{* *} \\
{[0.013]}\end{array}$ & $\begin{array}{l}-0.032^{* *} \\
{[0.029]}\end{array}$ & $\begin{array}{l}-0.037^{* *} \\
{[0.042]}\end{array}$ & $\begin{array}{l}-0.032 \\
{[0.029]}\end{array}$ \\
\hline Political stability & & & & & & & & $\begin{array}{l}-0.024 \\
{[0.943]}\end{array}$ & $\begin{array}{l}-0.135 \\
{[0.751]}\end{array}$ & $\begin{array}{l}-0.208 \\
{[0.626]}\end{array}$ \\
\hline Rule of law & & & & & & & & & $\begin{array}{l}0.223 \\
{[0.657]}\end{array}$ & $\begin{array}{l}1.519 \\
{[0.183]}\end{array}$ \\
\hline Control of corruption & & & & & & & & & & $\begin{array}{l}-1.24 \\
{[0.205]}\end{array}$ \\
\hline Initial income per capita & & & & & & & & & & $\begin{array}{l}-0.721 \\
{[0.346]}\end{array}$ \\
\hline $\begin{array}{l}\text { Initial ease of business } \\
\text { regulations }\end{array}$ & & & & & & & & & & $\begin{array}{l}-0.128 \\
{[0.108]}\end{array}$ \\
\hline East Asia and Pacific & & & & & & & & & & $\begin{array}{l}0.812^{*} \\
{[0.095]}\end{array}$ \\
\hline Europe and Central Asia & & & & & & & & & & $\begin{array}{l}0.314 \\
{[0.647]}\end{array}$ \\
\hline OECD & & & & & & & & & & $\begin{array}{l}-1.634 \\
{[0.278]}\end{array}$ \\
\hline $\begin{array}{l}\text { Middle East and North } \\
\text { Africa }\end{array}$ & & & & & & & & & & $\begin{array}{l}0.124 \\
{[0.176]}\end{array}$ \\
\hline $\begin{array}{l}\text { Latin America and } \\
\text { Carribean }\end{array}$ & & & & & & & & & & $\begin{array}{l}0.957 \\
{[0.234]}\end{array}$ \\
\hline South Asia & & & & & & & & & & $\begin{array}{l}0.879 \\
{[0.768]}\end{array}$ \\
\hline Observations & 172 & 166 & 117 & 117 & 117 & 116 & 116 & 113 & 113 & 113 \\
\hline$R$-squared & 0.051 & 0.047 & 0.265 & 0.296 & 0.299 & 0.422 & 0.454 & 0.449 & 0.454 & 0.462 \\
\hline
\end{tabular}

p-Values in brackets. All standard errors used are Huber-White robust and clustered on the country. All regressions use a constant term (not shown).

${ }_{* * *}^{* *}$ Significance level is $1 \%$ or less.

** Significance level is $5 \%$ or less.

* Significance level is $10 \%$ or less.

Second, I utilize Freedom House data on financial freedom and government expenditures to capture changes in countries' political environment which might have an effect on the confidence of the private sector and, thus, on economic growth. These measures range from 0 (not free) to 100 (free). Financial freedom ranges from 10 to 90 in the sample, and average government expenditures is 65.13. Moreover, the Trade variable helps us control for the impact of trade openness on growth as well.

Third, to capture the different implications of changes in population, foreign direct investment, and fixed capital formation over this period, every regression equation includes these explanatory 
Table 5

Robustness checks.

\begin{tabular}{|c|c|c|c|c|c|c|c|c|c|c|}
\hline & $(1)$ & $(2)$ & (3) & $(4)$ & $(5)$ & $(6)$ & $(7)$ & $(8)$ & $(9)$ & $(10)$ \\
\hline \multicolumn{11}{|l|}{$\begin{array}{l}\text { Dependent variable: } \\
\text { Economic growth } \\
(09-10)\end{array}$} \\
\hline \multirow[t]{2}{*}{$\begin{array}{l}\text { Regulatory reforms } \\
(06-08)\end{array}$} & $0.182^{* *}$ & $0.143^{*}$ & $0.167^{* *}$ & $0.136^{*}$ & $0.132^{*}$ & $0.160^{* *}$ & $0.167^{* *}$ & $0.166^{* *}$ & $0.171^{* *}$ & $0.143^{*}$ \\
\hline & [0.015] & {$[0.052]$} & {$[0.036]$} & [0.088] & [0.098] & [0.029] & [0.019] & {$[0.024]$} & {$[0.022]$} & [0.051] \\
\hline \multirow[t]{2}{*}{$\begin{array}{l}\text { Foreign direct investment } \\
\quad(06-08)\end{array}$} & & -0.03 & -0.062 & -0.047 & -0.073 & -0.033 & -0.015 & -0.018 & -0.016 & -0.017 \\
\hline & & {$[0.423]$} & {$[0.201]$} & [0.330] & [0.224] & [0.548] & [0.787] & {$[0.752]$} & [0.785] & {$[0.761]$} \\
\hline \multirow[t]{2}{*}{$\begin{array}{l}\text { Fixed capital formation } \\
\text { growth }(06-08)\end{array}$} & & & $0.154^{* * * *}$ & $0.151^{* * *}$ & $0.154^{*}$ & $0.123^{* * * *}$ & $0.105^{* * *}$ & $0.104^{* * * *}$ & $0.108^{* * * *}$ & $0.121^{* * *}$ \\
\hline & & & {$[0.000]$} & {$[0.000]$} & {$[0.000]$} & {$[0.000]$} & {$[0.000]$} & {$[0.000]$} & {$[0.000]$} & {$[0.002]$} \\
\hline Population (06-08) & & & & $\begin{array}{l}0.000^{*} \\
{[0.033]}\end{array}$ & $\begin{array}{l}0.000^{*} \\
{[0.027]}\end{array}$ & $\begin{array}{l}0.000 \\
{[0.048]}\end{array}$ & $\begin{array}{l}0.000^{*} \\
{[0.084]}\end{array}$ & $\begin{array}{l}0.000^{*} \\
{[0.091]}\end{array}$ & $\begin{array}{l}0.000 \\
{[0.145]}\end{array}$ & $\begin{array}{l}0.000 \\
{[0.219]}\end{array}$ \\
\hline Trade (06-08) & & & & & $\begin{array}{l}0.005 \\
{[0.462]}\end{array}$ & $\begin{array}{l}0.005 \\
{[0.349]}\end{array}$ & $\begin{array}{l}0.007 \\
{[0.223]}\end{array}$ & $\begin{array}{l}0.007 \\
{[0.253]}\end{array}$ & $\begin{array}{l}0.007 \\
{[0.262]}\end{array}$ & $\begin{array}{l}0.007 \\
{[0.217]}\end{array}$ \\
\hline \multirow[t]{2}{*}{$\begin{array}{l}\text { Government spending } \\
\quad(06-08)\end{array}$} & & & & & & $0.050^{* * *}$ & $0.045^{* 1+}$ & $0.043^{*+*}$ & $0.046^{*+*}$ & $0.042^{* *+}$ \\
\hline & & & & & & {$[0.000]$} & {$[0.000]$} & {$[0.001]$} & {$[0.001]$} & {$[0.004]$} \\
\hline Financial freedom (06-08) & & & & & & & $\begin{array}{l}-0.035^{* *} \\
{[0.011]}\end{array}$ & $\begin{array}{l}-0.032^{* *} \\
{[0.030]}\end{array}$ & $\begin{array}{l}-0.038^{* *} \\
{[0.037]}\end{array}$ & $\begin{array}{l}-0.032 \\
{[0.027]}\end{array}$ \\
\hline Political stability (06-08) & & & & & & & & $\begin{array}{l}-0.124 \\
{[0.717]}\end{array}$ & $\begin{array}{l}-0.261 \\
{[0.540]}\end{array}$ & $\begin{array}{l}-0.319 \\
{[0.326]}\end{array}$ \\
\hline Rule of law (06-08) & & & & & & & & & $\begin{array}{l}0.277 \\
{[0.587]}\end{array}$ & $\begin{array}{l}1.698 \\
{[0.131]}\end{array}$ \\
\hline $\begin{array}{l}\text { Control of corruption } \\
\quad(06-08)\end{array}$ & & & & & & & & & & $\begin{array}{l}-1.387 \\
{[0.132]}\end{array}$ \\
\hline Initial income per capita & & & & & & & & & & $\begin{array}{l}-0.648 \\
{[0.147]}\end{array}$ \\
\hline $\begin{array}{l}\text { Initial ease of business } \\
\text { regulations }\end{array}$ & & & & & & & & & & $\begin{array}{l}-0.127 \\
{[0.247]}\end{array}$ \\
\hline Initial human capital & & & & & & & & & & $\begin{array}{l}-0.437 \\
{[0.328]}\end{array}$ \\
\hline East Asia and Pacific & & & & & & & & & & $\begin{array}{l}0.762^{*} \\
{[0.098]}\end{array}$ \\
\hline Europe and Central Asia & & & & & & & & & & $\begin{array}{l}0.214 \\
{[0.647]}\end{array}$ \\
\hline OECD & & & & & & & & & & $\begin{array}{l}-1.367 \\
{[0.164]}\end{array}$ \\
\hline $\begin{array}{l}\text { Middle East and North } \\
\text { Africa }\end{array}$ & & & & & & & & & & $\begin{array}{l}0.124 \\
{[0.198]}\end{array}$ \\
\hline $\begin{array}{l}\text { Latin America and } \\
\text { Carribean }\end{array}$ & & & & & & & & & & $\begin{array}{l}0.951 \\
{[0.214]}\end{array}$ \\
\hline South Asia & & & & & & & & & & $\begin{array}{l}0.892 \\
{[0.745]}\end{array}$ \\
\hline Observations & 172 & 166 & 117 & 117 & 117 & 116 & 116 & 113 & 113 & 113 \\
\hline$R$-squared & 0.035 & 0.029 & 0.247 & 0.277 & 0.28 & 0.409 & 0.443 & 0.439 & 0.446 & 0.461 \\
\hline
\end{tabular}

p-Values in brackets. All standard errors used are Huber-White robust and clustered on the country. All regressions use a constant term (not shown).

**** Significance level is $1 \%$ or less.

** Significance level is $5 \%$ or less.

* Significance level is $10 \%$ or less.

variables. In a range of robustness checks, macroeconomic variables like inflation rates, real interest rates, and current account deficits were tested as controls as well. Their weak correlations with reform timing, however, led to a focus on sparser specifications. Moreover, I also control for initial status of 


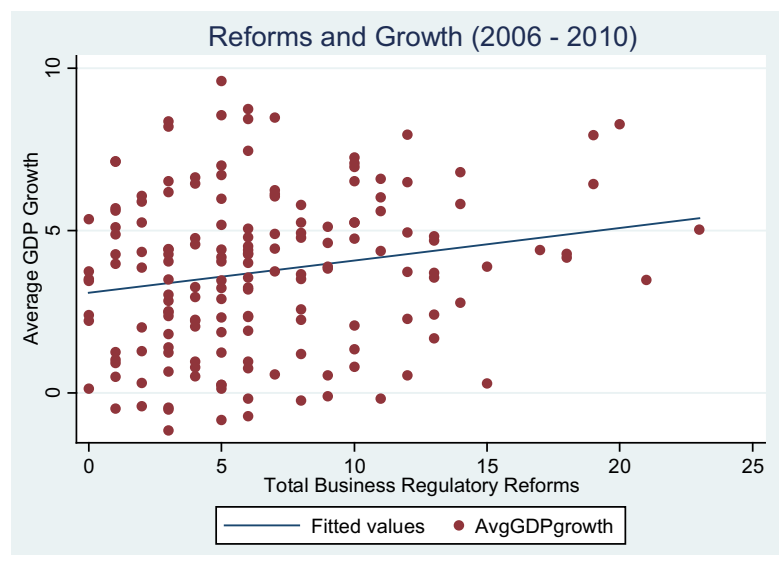

Fig. 1.

business regulatory environment, initial level of income, and dummy variables for each geographic region. ${ }^{5}$

\section{Main empirical results}

Fig. 1 illustrates the main empirical finding visually. The figure is a scatter plot showing the relationship between Reform and Growth on average over the sample period, and controlling for GDP per capita and country fixed effects. This regression is of average values of growth on total business regulatory reforms and other controls taken over the sample period (2006-2010). There is suggestive slope, corresponding to a positive relationship between reforms and increases in GDP growth rates. In addition, the confidence intervals are not large and do not expand rapidly for big reforms. Overall, the existing data can support certain assertions one way or the other about the aggregate impacts of the micro regulatory reforms on economic growth regulations.

The main empirical results are provided in Table 4 . The estimated coefficient values and their significance levels are obtained using an ordinary least squares specification with Huber-White robust standard errors clustered at the country level. Without any additional controls, the estimated coefficient of Reform is positive equaling 0.150 , significant at the $1 \%$ level (column 1 ). In words, on average, each business regulatory reform is associated, on average, with a $0.15 \%$ increase in economic growth. Moving from the country with the least number of reforms (0) to the highest number of reforms (23) increases the growth rate by 3.45 percentage points. This is a large effect given that the mean value of the dependent variable is only 3.93 .

The estimated coefficient of the Reform variable remains large and statistically significant when I control for various proxies of institutions and economic variables (columns 2-10). The coefficient value is lowest when I control for corruption, equaling 0.114 significant at the $5 \%$ level (column 10 ). Controlling for foreign direct investment and fixed capital formation growth lowers the estimated coefficient of reform but keeps it statistically significant at the $1 \%$ level (columns 2 and 3 ). In addition, the estimated coefficient value of Reform remains positive, economically large and statistically significant at less than the $5 \%$ level even after controlling for population size and trade openness (columns 4 and 5). However, the coefficient value does decline in magnitude from 0.150 (column 1 ) to 0.128 (column 5). This decline is almost entirely due to the control for foreign direct investment and trade. These two measures are negatively correlated with Growth.

Given that controlling for trade and investment levels had a fairly large effect on the estimated coefficient value of Reform, controlling for government expenditures and financial freedom, additional

\footnotetext{
${ }^{5}$ Specifically, I used (i) data on GDP per capita in the initial year to control for initial level of income as typically higher income countries tend to grow slower; and (ii) dummy variables for each geographic region.
} 
measures of overall financial development becomes more important. Columns (6-7) show that controlling for government expenditures and financial freedom has little effect on the estimated coefficient value of Reform, and the statistical level of the coefficient stays significant at $1 \%$. Unlike government spending, financial freedom shows a negative correlation with Reform less business climate reforms among the countries of relatively more financial freedom. Regarding the negative and significant coefficients on financial freedom variable, it is a result that initially causes a puzzle but does not contradict expectations. I am expecting that countries with higher levels of financial freedom would enjoy higher growth rates. Nevertheless, the sample period includes a financial crises time span, which affected more sharply countries with higher levels of financial freedom and more developed systems. Sure, other factors caused these countries (i.e. US, EU) to have lower growth rates too. This is why I do not consider the result as surprising in this particular context. More importantly, the result does not contradict my expectations given the main independent variable does not capture financial freedom.

Reasonably, countries of more political stability, rule of law, and control of corruption need less business regulatory reforms, as also exhibited in Table 3 . The largest impact on the estimated coefficient of Reform occurs when I control for corruption. It decreases from 0.150 (column1) to 0.114 (significant at the $1 \%$ level) due to the control of corruption (column 10). Importantly, the estimated coefficient value of Reform holds in terms of economic magnitude and remains statistically significant after controlling for each of the above economic variables.

In sum, growth is associated with micro-economic reforms, and this association remains strong when I control for various measures of institutional quality and economic variables. One concern with the results discussed above could be statistical significance. That is, while the magnitude of the estimated coefficient of Reform is not much affected by the various controls, its statistical significance level goes down to from $1 \%$ to $5 \%$ once I control for population, trade, and corruption. Does this mean that the results for the Growth-Reform relationship are somewhat weak? It is not necessarily the case because a $5 \%$ significance level is not necessarily weak. The next section shows that the results hold even after I allow a lagged impact of reform on growth. Hence, the stated weakness appears to be due to a specification bias. This matter makes the focus on the lagged impact much more important.

\section{Robustness}

I repeat the regression exercise using lagged reforms as well as country fixed effects estimators. The relationship between reforms and growth holds (Table 5). Unlike above, it is stronger in economic magnitude and still significant at the $5 \%$ and $10 \%$ levels when I control for FDI, population, and corruption. Based on the estimated coefficients, one additional business regulatory reform in a given country during 2006-2008 is associated, on average, with a $0.18 \%$ increase in its economic growth during 2009-2010.

Unlike other studies that do not go beyond whether a country reformed/not reformed or beyond counting the regulatory reforms, I consider the timing of reforms at the country-year level for two reasons. First, the availability of sequential reform information at the country level allows me to control for idiosyncratic patterns in the economic growth variable at the country level. Then, I do not worry about estimation bias due to unobserved controls that may drive differences in growth rates and are invariant during the sample period. Second, it helps me to partial out unobserved non-varying heterogeneity. For example, the fixed effects estimators that I use are valid in cases where economies with less flexible regulatory frameworks intervene more in their markets via the channel of state owned enterprises conditional on that such trends are time invariant.

Another worrisome zone is the co-movement of macroeconomic variables. If the timing of reforms is correlated with the business cycle, then the main regression in Table 5 will deliver biased coefficient estimates. And, in fact, such correlation can happen as output rates follow persistent, cyclical processes with substantial autocorrelation. One example can be when reforms take places during periods of prosperity. Then, the macroeconomic indicators move downward with the business cycles, causing the coefficients on reforms in Table 5 to be downward-biased. Another example can be when business regulatory reforms are motivated by and implemented during periods of macroeconomics downturns. 
Then, as a result, improvements in the economic framework of a country are expected regardless of whether reforms have any impact, causing the coefficients on reforms in Table 5 to be upward-biased.

This section relates changes in economic growth rates to changes in lagged values of regulatory indicators and control variables, conditional on the dynamics of the macroeconomic process of economic growth. A central difficulty in measuring the impact of a specific business regulatory reform on economic growth is inability to capture all other simultaneous actions. A fixed-effects regression exploiting variation within countries over time is capable of measuring impact of reform if the government actions are distributed over time. But, there is an omitted variables problem in the case where policy makers implement simultaneous reforms. For example, one government may improve the business regulatory framework during the same period that it provides more loans to small and medium enterprises. For this reason, specifically in order not to affiliate the impact of the unobserved policy (i.e. loans to SMEs in this case), I control for other institutional variables to address this potential problem.

Table 5 presents the robustness results. It includes total number of reforms and average data for main explanatory variables available for the period 2006-2008 as well as data on average growth rates between 2009 and 2010. I regress average economic growth on lagged reforms. The results for economic growth rates in all columns hold positive and statistically significant and validate the main results in Table 4. Without any other controls, on average, each additional reform during 2006-2008 is associated with a $0.182 \%$ increase in economic growth during 2009-2010 (column 1, Table 5). I controlled for all the variables reported in Table 4 simultaneously. The relationship between growth and reform remains robust to all these checks.

The hypothesis that I propose in the introduction - that business regulatory reforms have a positive impact on economic growth - cannot be rejected. The analysis shows that the $p$-values on business regulatory reform coefficients are statistically significant at conventional levels, and the confidence intervals widen substantially after including controls. I tried various ways to increase power by reducing multi-collinearity - i.e. by measuring the impact of reforms in each separate business regulatory area as well as by dropping controls - but the positive impact of business regulatory reforms holds.

\section{Conclusion}

With business regulatory reforms expanding significantly within countries and are being used as benchmark measures for success of policy makers, the link between the level of reforms and growth is receiving renewed interest. This study expands the previous literature based on anecdotal evidence and case studies of countries by using new and improved data. The findings confirm that an expansion of micro-economic reforms is likely to increase growth.

This paper studies the impact of business regulatory reforms on economic growth rates over the period 2006-2010. It uses cross-country differences in business regulatory reforms as well as variables that capture macroeconomic dynamics. The key empirical finding that we establish in this paper is: over the period 2006-2010, there is statistically significant evidence, across 172 countries, for economic growth response to business regulatory reforms. There is fairly robust evidence of positive impacts of regulatory reforms and these estimated impacts are sizeable and plausibly large. Each additional reform during $2006-2010$ is associated, on average, with a $0.15 \%$ increase in economic growth.

In addition, the onset of the global economic crisis has led to a slump in global economic growth. However, the extent to which economic growth has decreased differed among countries which reformed at least one area during the 3 years that preceded the recent financial crisis to those which did not. Using a unique micro, business regulatory reforms data from the World Bank Doing Business project, this study signals that reforms, which improved business and investment climate, may have helped to mitigate the effects of the 2008 global slump in economic growth. Countries with more business regulatory reforms enjoyed higher economic growth rates. Further research can look at whether countries that reformed more before the recent economic and financial crisis were less affected by the crisis.

\section{Acknowledgments}

The author would like to thank two anonymous referees and Takeo Hoshi for helpful comments and discussions as well as DIMeco (Île-de-France) for financial support. Fatima Zaid Bassam provided 
inspiration. The findings, interpretations, and conclusions expressed in this paper are entirely those of the author. They do not necessarily represent the views of the International Bank for Reconstruction and Development/World Bank and its affiliated organizations, or those of the Executive Directors of the World Bank or the governments they represent.

\section{Table A1}

Regression results - business entry.

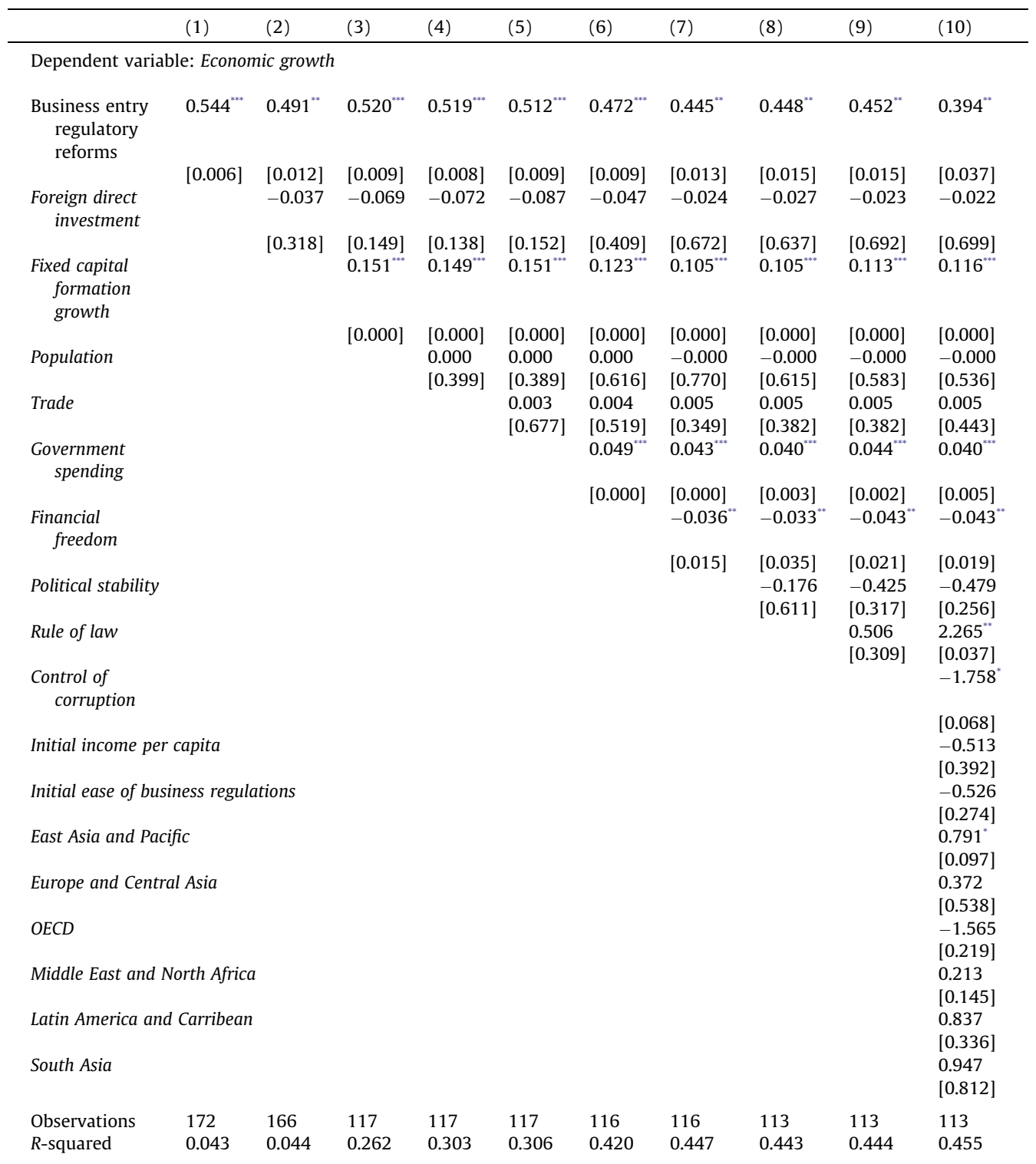

p-Values in brackets. All standard errors used are Huber-White robust and clustered on the country. All regressions use a constant term (not shown).

**** Significance level is $1 \%$ or less.

** Significance level is $5 \%$ or less.

* Significance level is $10 \%$ or less. 


\section{Appendix A}

See Tables A1-A10.

Table A2

Regression results - construction licenses.

\begin{tabular}{|c|c|c|c|c|c|c|c|c|c|c|}
\hline & $(1)$ & $(2)$ & (3) & (4) & (5) & (6) & (7) & (8) & (9) & $(10)$ \\
\hline \multicolumn{11}{|l|}{ Dependent variable: } \\
\hline \multirow{2}{*}{$\begin{array}{l}\text { Construction licenses } \\
\text { regulatory reforms }\end{array}$} & $0.225^{* * *}$ & $0.114^{* * *}$ & $0.211^{* * *}$ & $0.226^{* * *}$ & $0.113^{* * *}$ & $0.146^{* *}$ & $0.122^{* *}$ & $0.093^{*}$ & $0.066^{* *}$ & $0.117^{* *}$ \\
\hline & [0.007] & [0.005] & [0.009] & [0.009] & [0.009] & [0.026] & [0.049] & {$[0.073]$} & {$[0.038]$} & [0.046] \\
\hline \multirow[t]{2}{*}{ Foreign direct investment } & & -0.038 & -0.065 & -0.066 & -0.085 & -0.041 & -0.016 & -0.019 & -0.015 & -0.016 \\
\hline & & {$[0.314]$} & [0.193] & [0.188] & [0.173] & {$[0.486]$} & [0.783] & {$[0.747]$} & [0.797] & {$[0.786]$} \\
\hline \multirow{2}{*}{$\begin{array}{l}\text { Fixed capital formation } \\
\quad \text { growth }\end{array}$} & & & $0.158^{* * *+}$ & $0.158^{* * 8}$ & $0.160^{*+3 x}$ & $0.129^{* * *}$ & $0.108^{* * *}$ & $0.107^{* *+1}$ & $0.114^{* x+4}$ & $0.118^{* * *}$ \\
\hline & & & {$[0.000]$} & {$[0.000]$} & {$[0.000]$} & {$[0.000]$} & {$[0.000]$} & {$[0.000]$} & {$[0.000]$} & {$[0.000]$} \\
\hline \multirow{2}{*}{ Population } & & & & 0.000 & 0.000 & 0.000 & -0.000 & -0.000 & -0.000 & -0.000 \\
\hline & & & & {$[0.672]$} & {$[0.652]$} & [0.905] & [0.487] & [0.449] & {$[0.427]$} & {$[0.400]$} \\
\hline \multirow[t]{2}{*}{ Trade } & & & & & 0.003 & 0.004 & 0.006 & 0.006 & 0.006 & 0.005 \\
\hline & & & & & {$[0.602]$} & {$[0.470]$} & [0.305] & {$[0.312]$} & {$[0.315]$} & {$[0.386]$} \\
\hline \multirow[t]{2}{*}{ Government spending } & & & & & & $0.052^{* * *}$ & $0.046^{* * *}$ & $0.041^{* * *}$ & $0.045^{* * *}$ & $0.038^{* * * *}$ \\
\hline & & & & & & {$[0.000]$} & {$[0.000]$} & {$[0.003]$} & {$[0.002]$} & {$[0.008]$} \\
\hline \multirow[t]{2}{*}{ Financial freedom } & & & & & & & $-0.040^{* * * *}$ & $-0.036^{* *}$ & $-0.045^{* *}$ & -0.044 \\
\hline & & & & & & & {$[0.008]$} & {$[0.024]$} & {$[0.020]$} & {$[0.020]$} \\
\hline \multirow{2}{*}{ Political stability } & & & & & & & & -0.267 & -0.472 & -0.538 \\
\hline & & & & & & & & {$[0.461]$} & {$[0.281]$} & {$[0.211]$} \\
\hline \multirow[t]{2}{*}{ Rule of law } & & & & & & & & & 0.429 & $2.615^{* *}$ \\
\hline & & & & & & & & & [0.403] & [0.017] \\
\hline \multirow[t]{2}{*}{ Control of corruption } & & & & & & & & & & $-2.183^{*}$ \\
\hline & & & & & & & & & & [0.023] \\
\hline \multirow[t]{2}{*}{ Initial income per capita } & & & & & & & & & & -0.624 \\
\hline & & & & & & & & & & {$[0.437]$} \\
\hline \multirow{2}{*}{$\begin{array}{l}\text { Initial ease of business } \\
\quad \text { regulations }\end{array}$} & & & & & & & & & & -0.229 \\
\hline & & & & & & & & & & [0.115] \\
\hline \multirow[t]{2}{*}{ East Asia and Pacific } & & & & & & & & & & $0.903^{*}$ \\
\hline & & & & & & & & & & [0.097] \\
\hline \multirow[t]{2}{*}{ Europe and Central Asia } & & & & & & & & & & 0.343 \\
\hline & & & & & & & & & & {$[0.736]$} \\
\hline \multirow[t]{2}{*}{$O E C D$} & & & & & & & & & & -1.359 \\
\hline & & & & & & & & & & {$[0.318]$} \\
\hline \multirow{3}{*}{$\begin{array}{l}\text { Middle East and North } \\
\quad \text { Africa }\end{array}$} & & & & & & & & & & 0.235 \\
\hline & & & & & & & & & & \\
\hline & & & & & & & & & & [0.209] \\
\hline \multirow{2}{*}{$\begin{array}{l}\text { Latin America and } \\
\text { Carribean }\end{array}$} & & & & & & & & & & 0.896 \\
\hline & & & & & & & & & & {$[0.328]$} \\
\hline \multirow[t]{2}{*}{ South Asia } & & & & & & & & & & 0.786 \\
\hline & & & & & & & & & & {$[0.848]$} \\
\hline Observations & 172 & 166 & 117 & 117 & 117 & 116 & 116 & 113 & 113 & 113 \\
\hline$R$-squared & 0.005 & 0.008 & 0.217 & 0.218 & 0.220 & 0.350 & 0.391 & 0.389 & 0.393 & 0.423 \\
\hline
\end{tabular}

p-Values in brackets. All standard errors used are Huber-White robust and clustered on the country. All regressions use a constant term (not shown).

*** Significance level is $1 \%$ or less.

*** Significance level is $5 \%$ or less.

* Significance level is $10 \%$ or less. 
Table A3

Regression results - rigidity of labor.

\begin{tabular}{|c|c|c|c|c|c|c|c|c|c|c|}
\hline & $(1)$ & $(2)$ & (3) & $(4)$ & (5) & $(6)$ & (7) & $(8)$ & (9) & $(10)$ \\
\hline \multicolumn{11}{|l|}{$\begin{array}{l}\text { Dependent } \\
\text { variable: } \\
\text { Economic } \\
\text { growth }\end{array}$} \\
\hline \multirow{2}{*}{$\begin{array}{l}\text { Rigidity of labor } \\
\text { regulatory } \\
\text { reforms }\end{array}$} & $0.518^{* * * *}$ & $0.655^{* * *}$ & $0.693^{* * *}$ & $0.716^{* * *}$ & $0.692^{* *}$ & $0.811^{*}$ & $0.906^{* *}$ & $0.922^{* *}$ & $0.925^{* *}$ & $0.844^{*}$ \\
\hline & [0.003] & {$[0.001]$} & {$[0.001]$} & {$[0.004]$} & {$[0.016]$} & {$[0.074]$} & {$[0.040]$} & [0.043] & [0.043] & {$[0.061]$} \\
\hline \multirow{2}{*}{$\begin{array}{l}\text { Foreign direct } \\
\text { investment }\end{array}$} & & -0.034 & -0.056 & -0.057 & -0.067 & -0.019 & 0.010 & 0.006 & 0.010 & 0.007 \\
\hline & & {$[0.370]$} & {$[0.261]$} & [0.255] & {$[0.290]$} & {$[0.752]$} & [0.857] & {$[0.926]$} & {$[0.871]$} & {$[0.905]$} \\
\hline \multirow[t]{2}{*}{$\begin{array}{l}\text { Fixed capital } \\
\text { formation } \\
\text { growth }\end{array}$} & & & $0.157^{* * *}$ & $0.156^{* * *}$ & $0.158^{* * *}$ & $0.125^{* * *}$ & $0.103^{* * *}$ & $0.102^{* * * *}$ & $0.109^{* * * *}$ & $0.113^{* * * *}$ \\
\hline & & & {$[0.000]$} & {$[0.000]$} & {$[0.000]$} & {$[0.000]$} & {$[0.000]$} & {$[0.000]$} & {$[0.000]$} & {$[0.000]$} \\
\hline Population & & & & $\begin{array}{l}0.000 \\
{[0.584]}\end{array}$ & $\begin{array}{l}0.000 \\
{[0.578]}\end{array}$ & $\begin{array}{l}0.000 \\
{[0.800]}\end{array}$ & $\begin{array}{l}-0.000 \\
{[0.540]}\end{array}$ & $\begin{array}{l}-0.000 \\
{[0.553]}\end{array}$ & $\begin{array}{l}-0.000 \\
{[0.524]}\end{array}$ & $\begin{array}{l}-0.000 \\
{[0.493]}\end{array}$ \\
\hline Trade & & & & & $\begin{array}{l}0.002 \\
{[0.788]}\end{array}$ & $\begin{array}{l}0.002 \\
{[0.699]}\end{array}$ & $\begin{array}{l}0.004 \\
{[0.502]}\end{array}$ & $\begin{array}{l}0.005 \\
{[0.459]}\end{array}$ & $\begin{array}{l}0.005 \\
{[0.457]}\end{array}$ & $\begin{array}{l}0.004 \\
{[0.536]}\end{array}$ \\
\hline \multirow[t]{2}{*}{$\begin{array}{r}\text { Government } \\
\text { spending }\end{array}$} & & & & & & $0.053^{* * *}$ & $0.046^{* * * *}$ & $0.040^{* * * *}$ & $0.044^{* * *}$ & $0.039^{* * *}$ \\
\hline & & & & & & {$[0.000]$} & {$[0.000]$} & [0.003] & {$[0.002]$} & {$[0.006]$} \\
\hline Financial freedom & & & & & & & $\begin{array}{l}-0.042^{* * *} \\
{[0.004]}\end{array}$ & $\begin{array}{l}-0.038^{* *} \\
{[0.014]}\end{array}$ & $\begin{array}{l}-0.047^{* *} \\
{[0.011]}\end{array}$ & $\begin{array}{l}-0.047^{* *} \\
{[0.011]}\end{array}$ \\
\hline Political stability & & & & & & & & $\begin{array}{l}-0.315 \\
{[0.368]}\end{array}$ & $\begin{array}{l}-0.539 \\
{[0.210]}\end{array}$ & $\begin{array}{l}-0.585 \\
{[0.167]}\end{array}$ \\
\hline Rule of law & & & & & & & & & $\begin{array}{l}0.451 \\
{[0.367]}\end{array}$ & $\begin{array}{l}2.462^{* *} \\
{[0.022]}\end{array}$ \\
\hline $\begin{array}{l}\text { Control of } \\
\text { corruption }\end{array}$ & & & & & & & & & & $\begin{array}{l}-1.999^{* *} \\
{[0.035]}\end{array}$ \\
\hline $\begin{array}{l}\text { Initial income per } \\
\text { capita }\end{array}$ & & & & & & & & & & -0.435 \\
\hline \multirow[t]{2}{*}{$\begin{array}{l}\text { Initial ease of } \\
\quad \text { business } \\
\text { regulations }\end{array}$} & & & & & & & & & & -0.318 \\
\hline & & & & & & & & & & [0.229] \\
\hline $\begin{array}{l}\text { East Asia and } \\
\text { Pacific }\end{array}$ & & & & & & & & & & $\begin{array}{l}0.714^{*} \\
{[0.062]}\end{array}$ \\
\hline $\begin{array}{l}\text { Europe and } \\
\quad \text { Central Asia }\end{array}$ & & & & & & & & & & $\begin{array}{l}0.529 \\
{[0.675]}\end{array}$ \\
\hline$O E C D$ & & & & & & & & & & $\begin{array}{l}-1.247 \\
{[0.257]}\end{array}$ \\
\hline $\begin{array}{l}\text { Middle East and } \\
\quad \text { North Africa }\end{array}$ & & & & & & & & & & $\begin{array}{l}0.364 \\
{[0.327]}\end{array}$ \\
\hline $\begin{array}{l}\text { Latin America and } \\
\text { Carribean }\end{array}$ & & & & & & & & & & $\begin{array}{l}0.781 \\
{[0.247]}\end{array}$ \\
\hline South Asia & & & & & & & & & & $\begin{array}{l}0.567 \\
{[0.426]}\end{array}$ \\
\hline Observations & 172 & 166 & 117 & 117 & 117 & 116 & 116 & 113 & 113 & 113 \\
\hline$R$-squared & 0.006 & 0.017 & 0.231 & 0.233 & 0.233 & 0.368 & 0.414 & 0.412 & 0.416 & 0.441 \\
\hline
\end{tabular}

p-Values in brackets. All standard errors used are Huber-White robust and clustered on the country. All regressions use a constant term (not shown).

${ }^{* * * *}$ Significance level is $1 \%$ or less.

** Significance level is $5 \%$ or less.

* Significance level is $10 \%$ or less. 
Table A4

Regression results - property registration.

\begin{tabular}{|c|c|c|c|c|c|c|c|c|c|c|}
\hline & $(1)$ & $(2)$ & (3) & $(4)$ & $(5)$ & (6) & $(7)$ & $(8)$ & $(9)$ & $(10)$ \\
\hline \multicolumn{11}{|l|}{$\begin{array}{l}\text { Dependent } \\
\text { variable: } \\
\text { Economic growth }\end{array}$} \\
\hline \multirow{2}{*}{$\begin{array}{l}\text { Property } \\
\quad \text { registration } \\
\text { regulatory } \\
\text { reforms }\end{array}$} & $0.026^{* *}$ & $0.017^{* *}$ & $0.077^{*}$ & $0.099^{*}$ & $0.093^{*}$ & $0.019^{*}$ & $0.019^{* * *}$ & $0.021^{* * *}$ & $0.025^{* *}$ & $0.013^{*}$ \\
\hline & [0.043] & {$[0.050]$} & {$[0.081]$} & {$[0.075]$} & {$[0.076]$} & {$[0.052]$} & [0.047] & [0.045] & {$[0.042]$} & {$[0.065]$} \\
\hline \multirow{2}{*}{$\begin{array}{l}\text { Foreign direct } \\
\text { investment }\end{array}$} & & -0.038 & -0.066 & -0.067 & -0.086 & -0.043 & -0.018 & -0.022 & -0.018 & -0.017 \\
\hline & & {$[0.321]$} & [0.187] & {$[0.180]$} & [0.168] & {$[0.458]$} & {$[0.749]$} & [0.709] & {$[0.760]$} & [0.765] \\
\hline \multirow{2}{*}{$\begin{array}{l}\text { Fixed capital } \\
\text { formation } \\
\text { growth }\end{array}$} & & & $0.158^{* * * *}$ & $0.157^{* * * *}$ & $0.160^{* * * *}$ & $0.128^{* * * *}$ & $0.107^{* * * *}$ & $0.106^{* * *}$ & $0.113^{* * * *}$ & $0.118^{* * * *}$ \\
\hline & & & {$[0.000]$} & {$[0.000]$} & {$[0.000]$} & {$[0.000]$} & {$[0.000]$} & {$[0.000]$} & {$[0.000]$} & {$[0.000]$} \\
\hline Population & & & & $\begin{array}{l}0.000 \\
{[0.643]}\end{array}$ & $\begin{array}{l}0.000 \\
{[0.625]}\end{array}$ & $\begin{array}{l}0.000 \\
{[0.829]}\end{array}$ & $\begin{array}{l}-0.000 \\
{[0.550]}\end{array}$ & $\begin{array}{l}-0.000 \\
{[0.487]}\end{array}$ & $\begin{array}{l}-0.000 \\
{[0.461]}\end{array}$ & $\begin{array}{l}-0.000 \\
{[0.426]}\end{array}$ \\
\hline Trade & & & & & $\begin{array}{l}0.003 \\
{[0.606]}\end{array}$ & $\begin{array}{l}0.004 \\
{[0.488]}\end{array}$ & $\begin{array}{l}0.006 \\
{[0.315]}\end{array}$ & $\begin{array}{l}0.006 \\
{[0.335]}\end{array}$ & $\begin{array}{l}0.006 \\
{[0.334]}\end{array}$ & $\begin{array}{l}0.005 \\
{[0.407]}\end{array}$ \\
\hline \multirow[t]{2}{*}{$\begin{array}{r}\text { Government } \\
\text { spending }\end{array}$} & & & & & & $0.052^{* * * *}$ & $0.046^{* * * *}$ & $0.041^{* * * *}$ & $0.046^{* * *}$ & $0.040^{* * *}$ \\
\hline & & & & & & {$[0.000]$} & {$[0.000]$} & {$[0.003]$} & {$[0.002]$} & {$[0.006]$} \\
\hline Financial freedom & & & & & & & $\begin{array}{l}-0.040^{* * * *} \\
{[0.008]}\end{array}$ & $\begin{array}{l}-0.037^{* *} \\
{[0.021]}\end{array}$ & $\begin{array}{l}-0.046^{* *} \\
{[0.016]}\end{array}$ & $\begin{array}{l}-0.045^{* *} \\
{[0.015]}\end{array}$ \\
\hline Political stability & & & & & & & & $\begin{array}{l}-0.241 \\
{[0.496]}\end{array}$ & $\begin{array}{l}-0.472 \\
{[0.278]}\end{array}$ & $\begin{array}{l}-0.523 \\
{[0.222]}\end{array}$ \\
\hline Rule of law & & & & & & & & & $\begin{array}{l}0.467 \\
{[0.359]}\end{array}$ & $\begin{array}{l}2.551^{* *} \\
{[0.020]}\end{array}$ \\
\hline $\begin{array}{l}\text { Control of } \\
\text { corruption }\end{array}$ & & & & & & & & & & $-2.080^{* *}$ \\
\hline $\begin{array}{l}\text { Initial income per } \\
\quad \text { capita }\end{array}$ & & & & & & & & & & -0.556 \\
\hline \multirow[t]{2}{*}{$\begin{array}{l}\text { Initial ease of } \\
\quad \text { business } \\
\text { regulations }\end{array}$} & & & & & & & & & & -0.294 \\
\hline & & & & & & & & & & {$[0.312]$} \\
\hline East Asia and Pacific & & & & & & & & & & $\begin{array}{l}0.925^{*} \\
{[0.071]}\end{array}$ \\
\hline $\begin{array}{l}\text { Europe and Central } \\
\quad \text { Asia }\end{array}$ & & & & & & & & & & 0.653 \\
\hline$O E C D$ & & & & & & & & & & $\begin{array}{l}{[0.726]} \\
-1.458 \\
{[0.579]}\end{array}$ \\
\hline $\begin{array}{l}\text { Middle East and } \\
\quad \text { North Africa }\end{array}$ & & & & & & & & & & $\begin{array}{l}0.272 \\
{[0.251]}\end{array}$ \\
\hline $\begin{array}{l}\text { Latin America and } \\
\text { Carribean }\end{array}$ & & & & & & & & & & 0.562 \\
\hline South Asia & & & & & & & & & & $\begin{array}{l}{[0.356]} \\
0.469 \\
{[0.347]}\end{array}$ \\
\hline Observations & 172 & 166 & 117 & 117 & 117 & 116 & 116 & 113 & 113 & 113 \\
\hline$R$-squared & 0.004 & 0.008 & 0.217 & 0.218 & 0.220 & 0.352 & 0.394 & 0.391 & 0.396 & 0.423 \\
\hline
\end{tabular}

p-Values in brackets. All standard errors used are Huber-White robust and clustered on the country. All regressions use a constant term (not shown).

*** Significance level is $1 \%$ or less.

** Significance level is $5 \%$ or less.

* Significance level is $10 \%$ or less. 


\section{Table A5i}

Regression results - getting credit information.

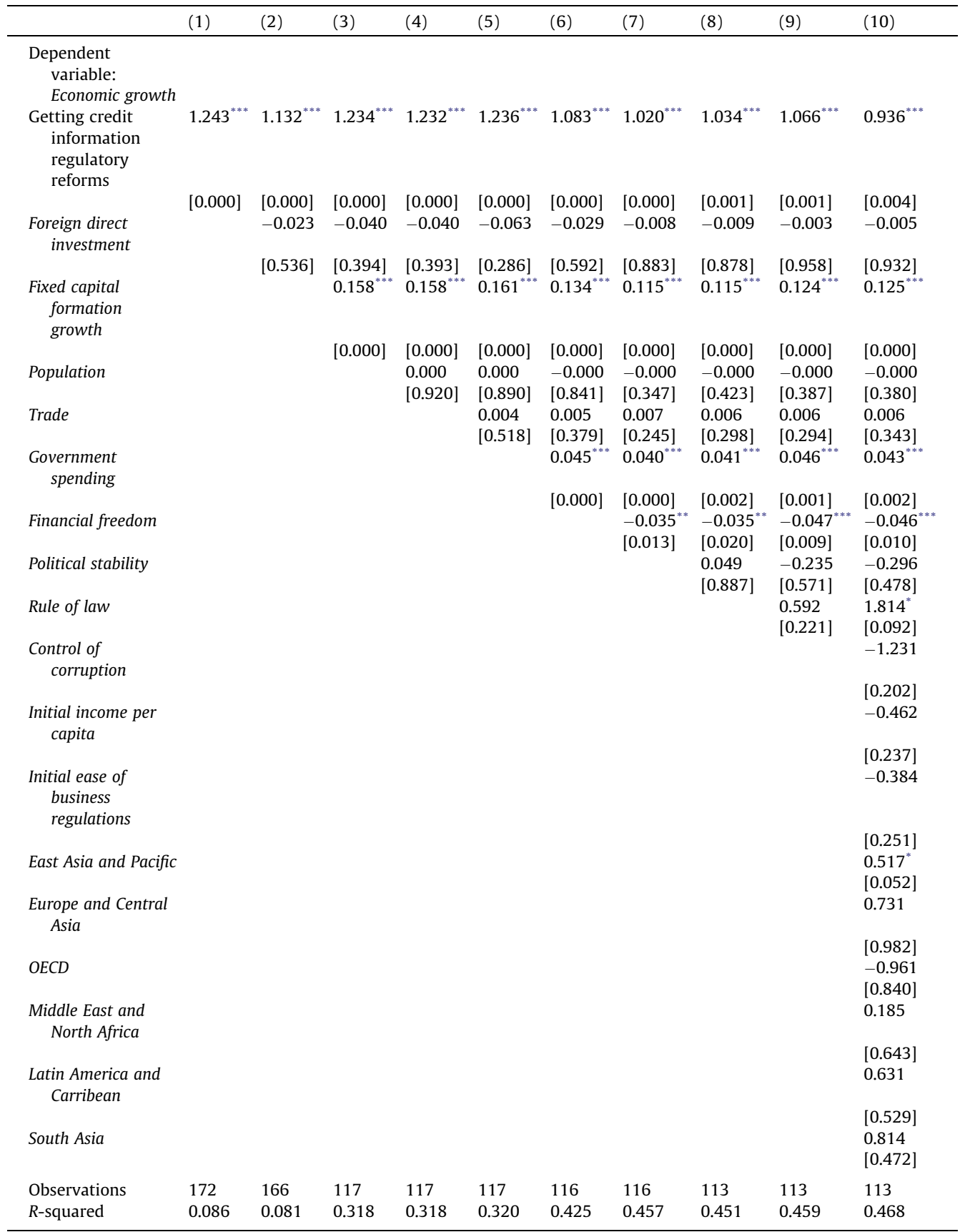

p-Values in brackets. All standard errors used are Huber-White robust and clustered on the country. All regressions use a constant term (not shown).

**** Significance level is $1 \%$ or less.

*** Significance level is $5 \%$ or less.

* Significance level is $10 \%$ or less. 
Table A5ii

Regression results - getting credit (legal rights).

\begin{tabular}{|c|c|c|c|c|c|c|c|c|c|c|}
\hline & (1) & (2) & (3) & (4) & (5) & (6) & (7) & $(8)$ & (9) & $(10)$ \\
\hline \multicolumn{11}{|l|}{$\begin{array}{l}\text { Dependent } \\
\text { variable: } \\
\text { Economic growth }\end{array}$} \\
\hline \multirow{2}{*}{$\begin{array}{l}\text { Getting credit } \\
\quad \text { (legal rights) } \\
\text { regulatory } \\
\text { reforms }\end{array}$} & $0.806^{*}$ & $0.866^{* *}$ & 0.661 & 0.676 & 0.668 & 0.587 & 0.569 & 0.519 & 0.521 & 0.421 \\
\hline & [0.051] & {$[0.032]$} & {$[0.128]$} & {$[0.122]$} & {$[0.128]$} & {$[0.145]$} & {$[0.146]$} & [0.198] & [0.197] & [0.291] \\
\hline \multirow{2}{*}{$\begin{array}{l}\text { Foreign direct } \\
\text { investment }\end{array}$} & & -0.037 & -0.065 & -0.067 & -0.084 & -0.041 & -0.016 & -0.019 & -0.015 & -0.016 \\
\hline & & {$[0.320]$} & {$[0.182]$} & {$[0.176]$} & {$[0.174]$} & {$[0.477]$} & {$[0.773]$} & [0.743] & [0.795] & [0.785] \\
\hline \multirow{2}{*}{$\begin{array}{l}\text { Fixed capital } \\
\text { formation } \\
\text { growth }\end{array}$} & & & $0.155^{* * * *}$ & $0.154^{* * * *}$ & $0.156^{* * * *}$ & $0.126^{* * * *}$ & $0.106^{* * * *}$ & $0.105^{* * *}$ & $0.112^{* * * *}$ & $0.116^{* * * *}$ \\
\hline & & & {$[0.000]$} & {$[0.000]$} & {$[0.000]$} & {$[0.000]$} & {$[0.000]$} & {$[0.000]$} & {$[0.000]$} & {$[0.000]$} \\
\hline Population & & & & $\begin{array}{l}0.000 \\
{[0.598]}\end{array}$ & $\begin{array}{l}0.000 \\
{[0.581]}\end{array}$ & $\begin{array}{l}0.000 \\
{[0.828]}\end{array}$ & $\begin{array}{l}-0.000 \\
{[0.546]}\end{array}$ & $\begin{array}{l}-0.000 \\
{[0.529]}\end{array}$ & $\begin{array}{l}-0.000 \\
{[0.502]}\end{array}$ & $\begin{array}{l}-0.000 \\
{[0.466]}\end{array}$ \\
\hline Trade & & & & & $\begin{array}{l}0.003 \\
{[0.640]}\end{array}$ & $\begin{array}{l}0.004 \\
{[0.507]}\end{array}$ & $\begin{array}{l}0.006 \\
{[0.330]}\end{array}$ & $\begin{array}{l}0.006 \\
{[0.345]}\end{array}$ & $\begin{array}{l}0.006 \\
{[0.344]}\end{array}$ & $\begin{array}{l}0.005 \\
{[0.418]}\end{array}$ \\
\hline \multirow[t]{2}{*}{$\begin{array}{r}\text { Government } \\
\text { spending }\end{array}$} & & & & & & $0.051^{* * *}$ & $0.045^{* * *}$ & $0.041^{* * * *}$ & $0.045^{* * *}$ & $0.040^{* * *}$ \\
\hline & & & & & & {$[0.000]$} & {$[0.000]$} & [0.003] & {$[0.002]$} & {$[0.006]$} \\
\hline Financial freedom & & & & & & & $\begin{array}{l}-0.040^{* * * *} \\
{[0.008]}\end{array}$ & $\begin{array}{l}-0.037^{* *} \\
{[0.020]}\end{array}$ & $\begin{array}{l}-0.046^{* *} \\
{[0.015]}\end{array}$ & $\begin{array}{l}-0.045^{* *} \\
{[0.014]}\end{array}$ \\
\hline Political stability & & & & & & & & $\begin{array}{l}-0.190 \\
{[0.592]}\end{array}$ & $\begin{array}{l}-0.411 \\
{[0.344]}\end{array}$ & $\begin{array}{l}-0.475 \\
{[0.267]}\end{array}$ \\
\hline Rule of law & & & & & & & & & $\begin{array}{l}0.447 \\
{[0.377]}\end{array}$ & $\begin{array}{l}2.492^{* *} \\
{[0.022]}\end{array}$ \\
\hline $\begin{array}{l}\text { Control of } \\
\text { corruption }\end{array}$ & & & & & & & & & & $-2.032^{* *}$ \\
\hline $\begin{array}{l}\text { Initial income per } \\
\quad \text { capita }\end{array}$ & & & & & & & & & & $\begin{array}{l}-0.371 \\
{[0.358]}\end{array}$ \\
\hline \multirow[t]{2}{*}{$\begin{array}{l}\text { Initial ease of } \\
\quad \text { business } \\
\text { regulations }\end{array}$} & & & & & & & & & & -0.274 \\
\hline & & & & & & & & & & [0.163] \\
\hline East Asia and Pacific & & & & & & & & & & $\begin{array}{l}0.328^{*} \\
{[0.066]}\end{array}$ \\
\hline $\begin{array}{l}\text { Europe and Central } \\
\quad \text { Asia }\end{array}$ & & & & & & & & & & 0.842 \\
\hline$O E C D$ & & & & & & & & & & $\begin{array}{l}{[0.751]} \\
-0.862 \\
{[0.725]}\end{array}$ \\
\hline $\begin{array}{l}\text { Middle East and } \\
\quad \text { North Africa }\end{array}$ & & & & & & & & & & $\begin{array}{l}0.293 \\
{[0.724]}\end{array}$ \\
\hline $\begin{array}{l}\text { Latin America and } \\
\text { Carribean }\end{array}$ & & & & & & & & & & $\begin{array}{l}0.542 \\
{[0.386]}\end{array}$ \\
\hline South Asia & & & & & & & & & & $\begin{array}{l}0.651 \\
{[0.639]}\end{array}$ \\
\hline Observations & 172 & 166 & 117 & 117 & 117 & 116 & 116 & 113 & 113 & 113 \\
\hline$R$-squared & 0.022 & 0.034 & 0.232 & 0.234 & 0.236 & 0.362 & 0.403 & 0.398 & 0.402 & 0.428 \\
\hline
\end{tabular}

p-Values in brackets. All standard errors used are Huber-White robust and clustered on the country. All regressions use a constant term (not shown).

**** Significance level is $1 \%$ or less.

** Significance level is $5 \%$ or less.

* Significance level is $10 \%$ or less. 
Table A6

Regression results - investors protections.

\begin{tabular}{|c|c|c|c|c|c|c|c|c|c|c|}
\hline & (1) & (2) & (3) & (4) & (5) & (6) & (7) & $(8)$ & (9) & (10) \\
\hline \multicolumn{11}{|l|}{$\begin{array}{l}\text { Dependent variable: } \\
\text { Economic growth }\end{array}$} \\
\hline \multirow{2}{*}{$\begin{array}{l}\text { Investors } \\
\text { protections } \\
\text { regulatory } \\
\text { reforms }\end{array}$} & $0.543^{* *}$ & $0.407^{* *}$ & $0.526^{* *}$ & $0.533^{* *}$ & $0.527^{* *}$ & $0.577^{* *}$ & $0.517^{* *}$ & $0.494^{* *}$ & $0.447^{* *}$ & $0.493^{* *}$ \\
\hline & {$[0.016]$} & [0.029] & {$[0.016]$} & {$[0.016]$} & {$[0.017]$} & [0.047] & {$[0.012]$} & {$[0.016]$} & {$[0.021]$} & {$[0.026]$} \\
\hline \multirow{2}{*}{$\begin{array}{l}\text { Foreign direct } \\
\text { investment }\end{array}$} & & -0.035 & -0.062 & -0.063 & -0.081 & -0.036 & -0.013 & -0.015 & -0.013 & -0.013 \\
\hline & & {$[0.360]$} & [0.209] & [0.203] & [0.193] & {$[0.530]$} & {$[0.822]$} & [0.792] & {$[0.823]$} & [0.815] \\
\hline \multirow[t]{2}{*}{$\begin{array}{l}\text { Fixed capital } \\
\quad \text { formation growth }\end{array}$} & & & $0.158^{* * *}$ & $0.158^{* * *}$ & $0.160^{* * *}$ & $0.129^{* * * *}$ & $0.109^{* * * *}$ & $0.107^{* * *}$ & $0.112^{* * *}$ & $0.116^{* * * *}$ \\
\hline & & & {$[0.000]$} & {$[0.000]$} & {$[0.000]$} & {$[0.000]$} & {$[0.000]$} & {$[0.000]$} & {$[0.000]$} & {$[0.000]$} \\
\hline Population & & & & $\begin{array}{l}0.000 \\
{[0.629]}\end{array}$ & $\begin{array}{l}0.000 \\
{[0.611]}\end{array}$ & $\begin{array}{l}0.000 \\
{[0.855]}\end{array}$ & $\begin{array}{l}-0.000 \\
{[0.536]}\end{array}$ & $\begin{array}{l}-0.000 \\
{[0.546]}\end{array}$ & $\begin{array}{l}-0.000 \\
{[0.520]}\end{array}$ & $\begin{array}{l}-0.000 \\
{[0.504]}\end{array}$ \\
\hline Trade & & & & & $\begin{array}{l}0.003 \\
{[0.628]}\end{array}$ & $\begin{array}{l}0.004 \\
{[0.500]}\end{array}$ & $\begin{array}{l}0.006 \\
{[0.328]}\end{array}$ & $\begin{array}{l}0.006 \\
{[0.359]}\end{array}$ & $\begin{array}{l}0.006 \\
{[0.355]}\end{array}$ & $\begin{array}{l}0.005 \\
{[0.448]}\end{array}$ \\
\hline \multirow[t]{2}{*}{$\begin{array}{r}\text { Government } \\
\text { spending }\end{array}$} & & & & & & $0.052^{* * *}$ & $0.046^{* * *}$ & $0.043^{* * * *}$ & $0.045^{* * *}$ & $0.039^{* * * *}$ \\
\hline & & & & & & {$[0.000]$} & {$[0.000]$} & {$[0.002]$} & {$[0.002]$} & {$[0.006]$} \\
\hline Financial freedom & & & & & & & $\begin{array}{l}-0.039^{* *} \\
{[0.010]}\end{array}$ & $\begin{array}{l}-0.036^{* *} \\
{[0.024]}\end{array}$ & $\begin{array}{l}-0.042^{* *} \\
{[0.028]}\end{array}$ & $\begin{array}{l}-0.041^{* *} \\
{[0.028]}\end{array}$ \\
\hline Political stability & & & & & & & & $\begin{array}{l}-0.167 \\
{[0.638]}\end{array}$ & $\begin{array}{l}-0.322 \\
{[0.471]}\end{array}$ & $\begin{array}{l}-0.368 \\
{[0.401]}\end{array}$ \\
\hline Rule of law & & & & & & & & & $\begin{array}{l}0.300 \\
{[0.563]}\end{array}$ & $\begin{array}{l}2.521^{* *} \\
{[0.020]}\end{array}$ \\
\hline Control of corruption & & & & & & & & & & $\begin{array}{l}-2.222^{* *} \\
{[0.020]}\end{array}$ \\
\hline $\begin{array}{l}\text { Initial income per } \\
\quad \text { capita }\end{array}$ & & & & & & & & & & $\begin{array}{l}-0.428 \\
{[0.465]}\end{array}$ \\
\hline \multirow[t]{2}{*}{$\begin{array}{l}\text { Initial ease of } \\
\quad \text { business } \\
\text { regulations }\end{array}$} & & & & & & & & & & -0.326 \\
\hline & & & & & & & & & & {$[0.243]$} \\
\hline East Asia and Pacific & & & & & & & & & & $\begin{array}{l}0.241^{*} \\
{[0.054]}\end{array}$ \\
\hline \multirow[t]{2}{*}{$\begin{array}{l}\text { Europe and Central } \\
\quad \text { Asia }\end{array}$} & & & & & & & & & & 0.842 \\
\hline & & & & & & & & & & {$[0.603]$} \\
\hline$O E C D$ & & & & & & & & & & $\begin{array}{l}-0.753 \\
{[0.637]}\end{array}$ \\
\hline $\begin{array}{l}\text { Middle East and } \\
\quad \text { North Africa }\end{array}$ & & & & & & & & & & 0.382 \\
\hline $\begin{array}{l}\text { Latin America and } \\
\text { Carribean }\end{array}$ & & & & & & & & & & $\begin{array}{l}0.653 \\
{[0.239]}\end{array}$ \\
\hline South Asia & & & & & & & & & & $\begin{array}{l}0.762 \\
{[0.743]}\end{array}$ \\
\hline Observations & 172 & 166 & 117 & 117 & 117 & 116 & 116 & 113 & 113 & 113 \\
\hline$R$-squared & 0.011 & 0.013 & 0.230 & 0.231 & 0.233 & 0.366 & 0.404 & 0.400 & 0.402 & 0.433 \\
\hline
\end{tabular}

p-Values in brackets. All standard errors used are Huber-White robust and clustered on the country. All regressions use a constant term (not shown).

Si*** Significance level is $1 \%$ or less.

** Significance level is $5 \%$ or less.

* Significance level is $10 \%$ or less. 
Table A7

Regression results - tax payments.

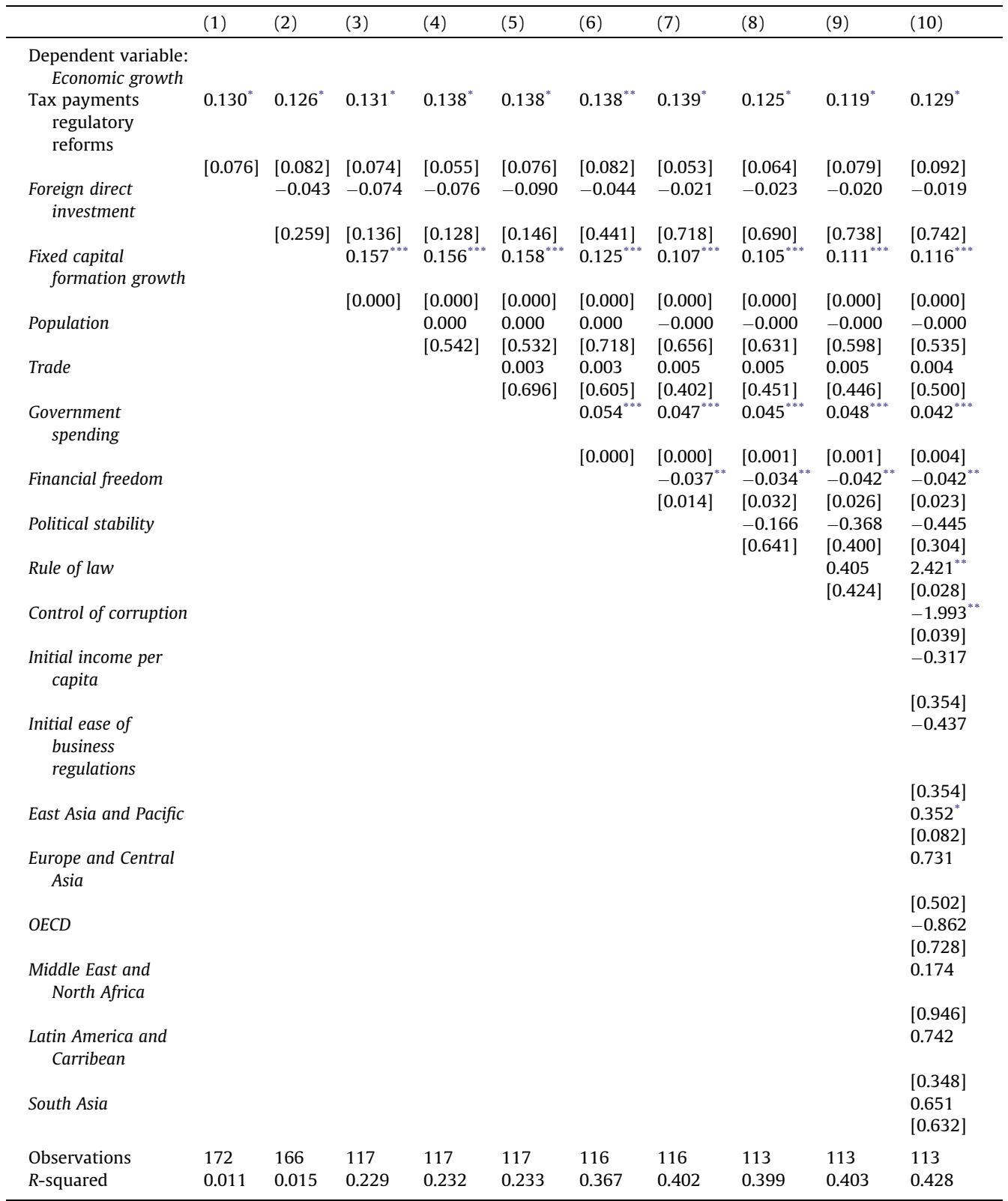

p-Values in brackets. All standard errors used are Huber-White robust and clustered on the country. All regressions use a constant term (not shown).

${ }^{* * *}$ Significance level is $1 \%$ or less.

*** Significance level is $5 \%$ or less.

* Significance level is $10 \%$ or less. 


\section{Table A8}

Regression results - importing/exporting.

\begin{tabular}{|c|c|c|c|c|c|c|c|c|c|c|}
\hline & $(1)$ & (2) & (3) & (4) & (5) & (6) & (7) & $(8)$ & (9) & $(10)$ \\
\hline \multicolumn{11}{|l|}{$\begin{array}{l}\text { Dependent } \\
\text { variable: } \\
\text { Economic growth }\end{array}$} \\
\hline Trading across & $0.881^{* * * *}$ & $0.786^{* * *}$ & $0.698^{* *}$ & $0.693^{* *}$ & $0.711^{* *}$ & $0.452^{*}$ & $0.438^{*}$ & $0.428^{*}$ & $0.433^{*}$ & $0.344^{*}$ \\
\hline & {$[0.000]$} & {$[0.002]$} & {$[0.011]$} & {$[0.012]$} & {$[0.010]$} & [0.085] & [0.087] & {$[0.096]$} & [0.092] & [0.093] \\
\hline \multirow{2}{*}{$\begin{array}{l}\text { Foreign direct } \\
\text { investment }\end{array}$} & & -0.028 & -0.048 & -0.049 & -0.077 & -0.040 & -0.016 & -0.018 & -0.014 & -0.015 \\
\hline & & {$[0.452]$} & {$[0.318]$} & {$[0.314]$} & {$[0.208]$} & {$[0.482]$} & [0.779] & {$[0.754]$} & [0.809] & {$[0.797]$} \\
\hline \multirow{2}{*}{$\begin{array}{l}\text { Fixed capital } \\
\text { formation } \\
\text { growth }\end{array}$} & & & $0.137^{* * * *}$ & $0.137^{* * * *}$ & $0.140^{* * * *}$ & $0.119^{* * * *}$ & $0.099^{* * *}$ & $0.099^{* * * *}$ & $0.106^{* * * *}$ & $0.111^{* * * *}$ \\
\hline & & & {$[0.000]$} & {$[0.000]$} & {$[0.000]$} & {$[0.000]$} & {$[0.001]$} & {$[0.001]$} & {$[0.001]$} & {$[0.000]$} \\
\hline Population & & & & $\begin{array}{l}0.000 \\
{[0.802]}\end{array}$ & $\begin{array}{l}0.000 \\
{[0.771]}\end{array}$ & $\begin{array}{l}0.000 \\
{[0.981]}\end{array}$ & $\begin{array}{l}-0.000 \\
{[0.431]}\end{array}$ & $\begin{array}{l}-0.000 \\
{[0.390]}\end{array}$ & $\begin{array}{l}-0.000 \\
{[0.365]}\end{array}$ & $\begin{array}{l}-0.000 \\
{[0.358]}\end{array}$ \\
\hline Trade & & & & & $\begin{array}{l}0.005 \\
{[0.446]}\end{array}$ & $\begin{array}{l}0.005 \\
{[0.380]}\end{array}$ & $\begin{array}{l}0.007 \\
{[0.236]}\end{array}$ & $\begin{array}{l}0.007 \\
{[0.277]}\end{array}$ & $\begin{array}{l}0.007 \\
{[0.275]}\end{array}$ & $\begin{array}{l}0.006 \\
{[0.352]}\end{array}$ \\
\hline $\begin{array}{r}\text { Government } \\
\text { spending }\end{array}$ & & & & & & $\begin{array}{l}0.047^{* * * *} \\
{[0.000]}\end{array}$ & $\begin{array}{l}0.041^{* * * *} \\
{[0.001]}\end{array}$ & $\begin{array}{l}0.038^{* * *} \\
{[0.005]}\end{array}$ & $\begin{array}{l}0.042^{* * *} \\
{[0.003]}\end{array}$ & $\begin{array}{l}0.038^{* * *} \\
{[0.009]}\end{array}$ \\
\hline Financial freedom & & & & & & & $\begin{array}{l}-0.040^{* * *} \\
{[0.008]}\end{array}$ & $\begin{array}{l}-0.037^{* *} \\
{[0.019]}\end{array}$ & $\begin{array}{l}-0.046^{* *} \\
{[0.014]}\end{array}$ & $\begin{array}{l}-0.045^{* *} \\
{[0.014]}\end{array}$ \\
\hline Political stability & & & & & & & & $\begin{array}{l}-0.145 \\
{[0.684]}\end{array}$ & $\begin{array}{r}-0.373 \\
{[0.390]}\end{array}$ & $\begin{array}{l}-0.443 \\
{[0.302]}\end{array}$ \\
\hline Rule of law & & & & & & & & & $\begin{array}{l}0.463 \\
{[0.358]}\end{array}$ & $\begin{array}{l}2.411^{* * *} \\
{[0.027]}\end{array}$ \\
\hline $\begin{array}{l}\text { Control of } \\
\text { corruption }\end{array}$ & & & & & & & & & & $-1.939^{* *}$ \\
\hline $\begin{array}{l}\text { Initial income per } \\
\quad \text { capita }\end{array}$ & & & & & & & & & & -0.667 \\
\hline $\begin{array}{l}\text { Initial ease of } \\
\quad \text { business } \\
\text { regulations }\end{array}$ & & & & & & & & & & -0.183 \\
\hline East Asia and Pacific & & & & & & & & & & $\begin{array}{l}{[0.401]} \\
0.836^{*} \\
{[0.084]}\end{array}$ \\
\hline $\begin{array}{l}\text { Europe and Central } \\
\quad \text { Asia }\end{array}$ & & & & & & & & & & 0.548 \\
\hline$O E C D$ & & & & & & & & & & $\begin{array}{l}-1.569 \\
{[0.680]}\end{array}$ \\
\hline $\begin{array}{l}\text { Middle East and } \\
\quad \text { North Africa }\end{array}$ & & & & & & & & & & $\begin{array}{l}0.383 \\
{[0.362]}\end{array}$ \\
\hline $\begin{array}{l}\text { Latin America and } \\
\text { Carribean }\end{array}$ & & & & & & & & & & $\begin{array}{l}0.673 \\
{[0.467]}\end{array}$ \\
\hline South Asia & & & & & & & & & & $\begin{array}{l}0.57 \\
{[0.458]}\end{array}$ \\
\hline Observations & 172 & 166 & 117 & 117 & 117 & 116 & 116 & 113 & 113 & 113 \\
\hline$R$-squared & 0.070 & 0.066 & 0.261 & 0.261 & 0.265 & 0.367 & 0.407 & 0.403 & 0.408 & 0.431 \\
\hline
\end{tabular}

p-Values in brackets. All standard errors used are Huber-White robust and clustered on the country. All regressions use a constant term (not shown).

**** Significance level is $1 \%$ or less.

** Significance level is $5 \%$ or less.

* Significance level is $10 \%$ or less. 
Table A9

Regression results - contract enforcement.

\begin{tabular}{|c|c|c|c|c|c|c|c|c|c|c|}
\hline & (1) & (2) & (3) & (4) & (5) & (6) & (7) & $(8)$ & (9) & (10) \\
\hline \multicolumn{11}{|l|}{$\begin{array}{l}\text { Dependent } \\
\text { variable: } \\
\text { Economic growth }\end{array}$} \\
\hline \multirow{2}{*}{$\begin{array}{l}\text { Contract } \\
\quad \text { enforcement } \\
\text { regulatory } \\
\text { reforms }\end{array}$} & 0.672 & 0.225 & 0.550 & 0.577 & 0.580 & $0.720^{* *}$ & $0.811^{* * *}$ & $0.817^{* *}$ & $0.811^{* * *}$ & $0.827^{* *}$ \\
\hline & {$[0.314]$} & {$[0.532]$} & [0.135] & {$[0.121]$} & [0.119] & {$[0.034]$} & {$[0.014]$} & [0.015] & [0.016] & {$[0.012]$} \\
\hline \multirow{2}{*}{$\begin{array}{l}\text { Foreign direct } \\
\text { investment }\end{array}$} & & -0.037 & -0.064 & -0.065 & -0.086 & -0.041 & -0.014 & -0.018 & -0.014 & -0.014 \\
\hline & & {$[0.330]$} & {$[0.195]$} & {$[0.187]$} & [0.165] & {$[0.477]$} & [0.807] & {$[0.760]$} & {$[0.811]$} & [0.799] \\
\hline \multirow{2}{*}{$\begin{array}{l}\text { Fixed capital } \\
\text { formation } \\
\text { growth }\end{array}$} & & & $0.159^{* * * *}$ & $0.159^{* * * *}$ & $0.161^{* * * *}$ & $0.129^{* * * *}$ & $0.107^{* * *}$ & $0.106^{* * * *}$ & $0.113^{* * * *}$ & $0.117^{* * *}$ \\
\hline & & & {$[0.000]$} & {$[0.000]$} & {$[0.000]$} & {$[0.000]$} & {$[0.000]$} & {$[0.000]$} & {$[0.000]$} & {$[0.000]$} \\
\hline Population & & & & $\begin{array}{l}0.000 \\
{[0.543]}\end{array}$ & $\begin{array}{l}0.000 \\
{[0.522]}\end{array}$ & $\begin{array}{l}0.000 \\
{[0.714]}\end{array}$ & $\begin{array}{l}-0.000 \\
{[0.607]}\end{array}$ & $\begin{array}{l}-0.000 \\
{[0.511]}\end{array}$ & $\begin{array}{l}-0.000 \\
{[0.485]}\end{array}$ & $\begin{array}{l}-0.000 \\
{[0.460]}\end{array}$ \\
\hline Trade & & & & & $\begin{array}{l}0.004 \\
{[0.574]}\end{array}$ & $\begin{array}{l}0.005 \\
{[0.437]}\end{array}$ & $\begin{array}{l}0.007 \\
{[0.257]}\end{array}$ & $\begin{array}{l}0.007 \\
{[0.271]}\end{array}$ & $\begin{array}{l}0.007 \\
{[0.271]}\end{array}$ & $\begin{array}{l}0.006 \\
{[0.343]}\end{array}$ \\
\hline \multirow[t]{2}{*}{$\begin{array}{r}\text { Government } \\
\text { spending }\end{array}$} & & & & & & $0.054^{* * * *}$ & $0.047^{* * * *}$ & $0.042^{* * * *}$ & $0.046^{* * * *}$ & $0.040^{* * * *}$ \\
\hline & & & & & & {$[0.000]$} & {$[0.000]$} & {$[0.002]$} & {$[0.001]$} & {$[0.005]$} \\
\hline Financial freedom & & & & & & & $\begin{array}{l}-0.043^{* * *} \\
{[0.003]}\end{array}$ & $\begin{array}{l}-0.040^{* *} \\
{[0.011]}\end{array}$ & $\begin{array}{l}-0.048^{* * *} \\
{[0.009]}\end{array}$ & $\begin{array}{l}-0.048^{* * *} \\
{[0.008]}\end{array}$ \\
\hline Political stability & & & & & & & & $\begin{array}{l}-0.249 \\
{[0.470]}\end{array}$ & $\begin{array}{l}-0.457 \\
{[0.281]}\end{array}$ & $\begin{array}{l}-0.516 \\
{[0.215]}\end{array}$ \\
\hline Rule of law & & & & & & & & & $\begin{array}{l}0.420 \\
{[0.396]}\end{array}$ & $\begin{array}{l}2.631^{* *} \\
{[0.013]}\end{array}$ \\
\hline $\begin{array}{l}\text { Control of } \\
\text { corruption }\end{array}$ & & & & & & & & & & $-2.196^{* *}$ \\
\hline $\begin{array}{l}\text { Initial income per } \\
\quad \text { capita }\end{array}$ & & & & & & & & & & -0.573 \\
\hline $\begin{array}{l}\text { Initial ease of } \\
\quad \text { business } \\
\quad \text { regulations }\end{array}$ & & & & & & & & & & -0.272 \\
\hline East Asia and Pacific & & & & & & & & & & $\begin{array}{l}{[0.513]} \\
0.745^{*} \\
{[0.065]}\end{array}$ \\
\hline $\begin{array}{l}\text { Europe and Central } \\
\quad \text { Asia }\end{array}$ & & & & & & & & & & $\begin{array}{l}0.346 \\
{[0.652]}\end{array}$ \\
\hline$O E C D$ & & & & & & & & & & $\begin{array}{l}-1.482 \\
{[0.564]}\end{array}$ \\
\hline $\begin{array}{c}\text { Middle East and } \\
\text { North Africa }\end{array}$ & & & & & & & & & & $\begin{array}{l}0.471 \\
{[0.236]}\end{array}$ \\
\hline $\begin{array}{l}\text { Latin America and } \\
\text { Carribean }\end{array}$ & & & & & & & & & & 0.713 \\
\hline South Asia & & & & & & & & & & $\begin{array}{l}0.751 \\
{[0.362]}\end{array}$ \\
\hline Observations & 172 & 166 & 117 & 117 & 117 & 116 & 116 & 113 & 113 & 113 \\
\hline$R$-squared & 0.006 & 0.009 & 0.232 & 0.234 & 0.237 & 0.376 & 0.424 & 0.422 & 0.426 & 0.456 \\
\hline
\end{tabular}

p-Values in brackets. All standard errors used are Huber-White robust and clustered on the country. All regressions use a constant term (not shown).

**** Significance level is $1 \%$ or less.

*** Significance level is $5 \%$ or less.

* Significance level is $10 \%$ or less. 


\section{Table A10}

Regression results - bankruptcy.

\begin{tabular}{|c|c|c|c|c|c|c|c|c|c|c|}
\hline & $(1)$ & $(2)$ & (3) & (4) & $(5)$ & (6) & $(7)$ & $(8)$ & (9) & $(10)$ \\
\hline $\begin{array}{l}\text { Dependent } \\
\text { variable: } \\
\text { Economic } \\
\text { growth }\end{array}$ & & & & & & & & & & \\
\hline $\begin{array}{l}\text { Bankruptcy } \\
\text { regulatory }\end{array}$ & $-0.723^{* *}$ & $-0.816^{* *}$ & $-0.838^{* *}$ & $-0.833^{* *}$ & $-0.824^{* *}$ & -0.374 & -0.250 & -0.265 & -0.266 & $-0.610^{*}$ \\
\hline & {$[0.044]$} & {$[0.020]$} & [0.018] & {$[0.019]$} & {$[0.021]$} & {$[0.280]$} & [0.463] & [0.447] & {$[0.446]$} & [0.092] \\
\hline $\begin{array}{l}\text { Foreign direct } \\
\text { investment }\end{array}$ & & $\begin{array}{l}-0.045 \\
{[0.235}\end{array}$ & $\begin{array}{l}-0.056 \\
{[0.244]}\end{array}$ & $\begin{array}{l}-0.057 \\
{[0.240]}\end{array}$ & $\begin{array}{l}-0.072 \\
{[0.243]}\end{array}$ & $\begin{array}{l}-0.038 \\
{[0.511]}\end{array}$ & $\begin{array}{l}-0.015 \\
{[0.792]}\end{array}$ & $\begin{array}{l}-0.018 \\
{[0.758]}\end{array}$ & $\begin{array}{l}-0.014 \\
{[0.810]}\end{array}$ & $\begin{array}{l}-0.014 \\
{[0.814]}\end{array}$ \\
\hline $\begin{array}{l}\text { Fixed capital } \\
\text { formation } \\
\text { growth }\end{array}$ & & & $0.152^{* * *}$ & $0.152^{* * *}$ & $0.153^{* * *}$ & $0.128^{* * * *}$ & $0.109^{* * *}$ & $0.107^{* * *}$ & $0.114^{* * * *}$ & $0.119^{* * * *}$ \\
\hline & & & {$[0.000]$} & {$[0.000]$} & {$[0.000]$} & {$[0.000]$} & {$[0.000]$} & {$[0.000]$} & {$[0.000]$} & {$[0.000]$} \\
\hline Population & & & & $\begin{array}{l}0.000 \\
{[0.745]}\end{array}$ & $\begin{array}{l}0.000 \\
{[0.728]}\end{array}$ & $\begin{array}{l}0.000 \\
{[0.928]}\end{array}$ & $\begin{array}{l}-0.000 \\
{[0.493]}\end{array}$ & $\begin{array}{l}-0.000 \\
{[0.483]}\end{array}$ & $\begin{array}{l}-0.000 \\
{[0.457]}\end{array}$ & $\begin{array}{l}-0.000 \\
{[0.457]}\end{array}$ \\
\hline Trade & & & & & $\begin{array}{l}0.002 \\
{[0.698]}\end{array}$ & $\begin{array}{l}0.004 \\
{[0.524]}\end{array}$ & $\begin{array}{l}0.006 \\
{[0.338]}\end{array}$ & $\begin{array}{l}0.006 \\
{[0.353]}\end{array}$ & $\begin{array}{l}0.006 \\
{[0.352]}\end{array}$ & $\begin{array}{l}0.004 \\
{[0.508]}\end{array}$ \\
\hline $\begin{array}{r}\text { Government } \\
\text { spending }\end{array}$ & & & & & & $\begin{array}{l}0.048^{* * *} \\
{[0.000]}\end{array}$ & $\begin{array}{l}0.043^{* * *} \\
{[0.000]}\end{array}$ & $\begin{array}{l}0.038^{* * *} \\
{[0.007]}\end{array}$ & $\begin{array}{l}0.042^{* * *} \\
{[0.005]}\end{array}$ & $\begin{array}{l}0.031^{* *} \\
{[0.036]}\end{array}$ \\
\hline Financial freedom & & & & & & & $\begin{array}{l}-0.039^{* *} \\
{[0.011]}\end{array}$ & $\begin{array}{l}-0.035^{* *} \\
{[0.030]}\end{array}$ & $\begin{array}{l}-0.044^{* *} \\
{[0.022]}\end{array}$ & $\begin{array}{l}-0.041^{* *} \\
{[0.027]}\end{array}$ \\
\hline Political stability & & & & & & & & $\begin{array}{l}-0.255 \\
{[0.471]}\end{array}$ & $\begin{array}{l}-0.476 \\
{[0.275]}\end{array}$ & $\begin{array}{l}-0.567 \\
{[0.181]}\end{array}$ \\
\hline Rule of law & & & & & & & & & $\begin{array}{l}0.445 \\
{[0.381]}\end{array}$ & $\begin{array}{l}3.205^{* * *} \\
{[0.005]}\end{array}$ \\
\hline $\begin{array}{l}\text { Control of } \\
\text { corruption }\end{array}$ & & & & & & & & & & $\begin{array}{l}-2.740^{* * *} \\
{[0.007]}\end{array}$ \\
\hline $\begin{array}{l}\text { Initial income per } \\
\quad \text { capita }\end{array}$ & & & & & & & & & & $\begin{array}{l}-0.673 \\
{[0.481]}\end{array}$ \\
\hline $\begin{array}{c}\text { Initial ease of } \\
\quad \text { business } \\
\text { regulations }\end{array}$ & & & & & & & & & & -0.294 \\
\hline & & & & & & & & & & {$[0.512]$} \\
\hline East Asia and Pacific & & & & & & & & & & $\begin{array}{l}0.725^{*} \\
{[0.073]}\end{array}$ \\
\hline $\begin{array}{l}\text { Europe and Central } \\
\quad \text { Asia }\end{array}$ & & & & & & & & & & $\begin{array}{l}0.659 \\
{[0.726]}\end{array}$ \\
\hline$O E C D$ & & & & & & & & & & $\begin{array}{l}-1.458 \\
{[0.571]}\end{array}$ \\
\hline $\begin{array}{l}\text { Middle East and } \\
\text { North Africa }\end{array}$ & & & & & & & & & & $\begin{array}{l}0.272 \\
{[0.471]}\end{array}$ \\
\hline $\begin{array}{l}\text { Latin America and } \\
\text { Carribean }\end{array}$ & & & & & & & & & & $\begin{array}{l}0.581 \\
{[0.356]}\end{array}$ \\
\hline South Asia & & & & & & & & & & $\begin{array}{l}0.681 \\
{[0.568]}\end{array}$ \\
\hline Observations & 172 & 166 & 117 & 117 & 117 & 116 & 116 & 113 & 113 & 113 \\
\hline$R$-squared & 0.024 & 0.039 & 0.254 & 0.255 & 0.256 & 0.356 & 0.394 & 0.391 & 0.396 & 0.438 \\
\hline
\end{tabular}

p-Values in brackets. All standard errors used are Huber-White robust and clustered on the country. All regressions use a constant term (not shown).

**** Significance level is $1 \%$ or less.

*** Significance level is $5 \%$ or less.

* Significance level is $10 \%$ or less. 


\section{References}

Acemoglu, D., Johnson, S., Robinson, A., 2001. The colonial origins of comparative development: an empirical investigation. Amer. Econ. Rev. 91 (5), 1369-1401.

Amin, M., Haidar, J.I., 2011. Trade Facilitations and Country Size. World Bank, Mimeograph.

Amin, M., Haidar, J.I., 2012. The cost of registering property: does legal origin matter? Empirical Econ. 42 (3), $1035-1050$.

Besley, T., Burgess, R., 2004. Can labor regulation hinder economic performance? Evidence from India. Quart. J. Econ. 119 (1), 91-134.

Conway, P., Janod, V., Nicoletti, G., 2005. Product Market Regulation in OECD Countries, 1998 to 2003. Economics Department Working Paper 419, OECD.

Kaufmann, D., Kraay, A., Mastruzzi, M., 2009. Governance matters VIII: aggregate and individual governance indicators 1996-2008. Policy Research Working Paper Series 4978, The World Bank..

Djankov, S., La Porta, R., Lopez-de-Silanes, F., Shleifer, A., 2002. The regulation of entry. Quart. J. Econ. 117 (1), 1-37.

Djankov, S., La Porta, R., Lopez-de-Silanes, F., Shleifer, A., 2003. Courts. Quart. J. Econ. 118 (2), 453-517.

Djankov, S., Botero, J., Porta, R., Lopez-De-Silanes, F.C., 2004. The regulation of labor. The Quarterly Journal of Economics 119 (4), 1339-1382.

Djankov, S., McLiesh, C., Ramalho, R., 2006. Regulation and growth. Econ. Letters 92 (3), 395-401.

Djankov, S., Freund, C., Pham, C., 2010. Trading on time. Rev. Econ. Statist. 92 (1), 166-173.

Desai, M., Gompers, P., Lerner, J., 2003. Institutions, Capital Constraints and Entrepreneurial Firm Dynamics: Evidence from Europe. NBER Working Paper 10165.

Haidar, J.I., 2009. Investor protections and economic growth. Econ. Letters 103 (1), 1-4.

Hall, R., Jones, C., 1999. Why do some countries produce so much more output per worker than others. Quart. J. Econ. 144 (1), 83-116.

Hasan, R., Mitra, D., Ramaswamy, K.V., 2007. Trade reforms, labor regulations, and labor-demand elasticities: empirical evidence from India. Rev. Econ. Statist. 89 (3), 466-481.

Klapper, L., Laeven, L., Rajan, R., 2004. Business Environment and Firm Entry: Evidence from International Data, CEPR Discussion Papers 4366.

OECD, World Bank, 2006. Emerging Good Practice in Managing for Development Results.

Scarpetta, S., Hemmings, P., Tressel, T., Woo, J., 2002. The Role of Policy and Institutions for Productivity and Firm Dynamics: Evidence from Micro and Industry Data, Economics Department working paper 329, OECD.

Viviano, E., 2008. Entry regulations and labour market outcomes: evidence from the Italian retail trade sector. Lab. Econ. 15 (6), $1200-1222$.

Winston, C., 1998. US industry adjustment to economic deregulation. J. Econ. Perspect. 12 (3), 89-110.

World Bank Doing Business Database. <http://www.doingbusiness.org>.

World Bank Doing Business 2004 Report. 